AROUEOLOGÍA Y SOCIEDAD

№ 25, 2012: 259-302

ISSN: 0254-8062

RECIBIDO: AGOSTO DE 2012

ACEPTADO: OCTUBRE DE 2012

\title{
CONTEXTOS FUNERARIOS CHANCAY EN MACATÓN, VALLE DE CHANCAY-HUARAL
}

\author{
Pieter VAN DALEN LUNA \\ UNIVERSIDAD NACIONAL MAYOR DE SAN MARCOS \\ pvandalen2@hotmail.com
}

\section{RESUMEN}

Se presentan los resultados de las investigaciones desarrolladas a comienzos del año 2009 en el sitio arqueológico de Cerro Macatón, uno de los sitios más importantes del valle bajo del río Chancay-Huaral. Este sitio, conformado por una extensa área funeraria con un sector con arquitectura residencial, ha sido el área funeraria más amplia del valle. Las excavaciones realizadas nos permitieron identificar varios contextos funerarios, en los cuales la recurrencia era la colocación del individuo al interior de fardos, lo que constituye una oportunidad de conocer las características de estos.

Palabras clave: Arqueología del valle Chancay-Huaral, cultura Chancay, contextos funerarios, Macatón.

\section{AbSTRACT}

We present the results of investigations carried out in early2009 at the archaeological site of Cerro Macatón, one of the most important sites in the lower valley of the river Chancay-Huaral. This site, consisting of a large funeral with a sector area with residential architecture has been the most extensive area of valley funeral. Excavations allowed us to identify several funerary contexts in which the recurrence was the placement of individuals with in bales, which is an opportunity to know their characteristics.

KEYwoRDS: Archaeology of the Chancay-Huaral valley, Chancay culture, funerary contexts, Macatón.

\section{INTRODUCCIÓN}

En enero de 2009, luego de muchas peripecias, se iniciaron los trabajos de excavación en el sitio arqueológico de Cerro Macatón. Pues, a pesar de que el presupuesto del proyecto fue aprobado desde 2007 y se contaba con una partida presupuestal para iniciar los trabajos y que en enero de 2008 se presentó el proyecto al Instituto Nacional de Cultura para su aprobación y autorización, a pesar de no haber tenido observaciones y haber pasado en cuatro oportunidades a la Comisión Nacional Técnica de Arqueología presidida por el Lic. Yuri Castro, esta comisión desaprobó el mencionado proyecto aduciendo que no podíamos realizar investigaciones en el sitio, pues solo podríamos hacer cateos en medio de las zonas agrícolas aledañas, ya que de excavar en el interior del sitio, obtendríamos mucho 
material cultural y los depósitos del INC estaban llenos. Algo paradójico, en un país donde solo el 2\% de los sitios arqueológicos han sido investigados y sus datos forman parte de la teoría sustancial de la arqueología, donde el INC, en lugar de fomentar y apoyar los proyectos de investigación arqueológica, pone trabas en cualquier intento de entidades públicas y privadas de invertir en cultura. Algo realmente sorprendente que las nuevas generaciones deberán juzgar. Pero, lo más sorprendente es que luego de ocho meses de encontrar negativa de dicha Comisión Técnica integrada además por los arqueólogos L. Casas, D. Pozzi y D. Casareto, y luego de haber perdido la partida presupuestal, recién en ese momento deciden aprobar el proyecto, limitándonos a realizar pozos de cateo restringidos. Fue gracias al importante apoyo de la empresa FAMESA Explosivos, que se logró realizar una corta temporada de campo de un mes y medio (enero y febrero), en la cual se excavó cinco unidades de 2 x $2 \mathrm{~m}$, en donde se halló los contextos funerarios que describiremos más adelante, y que son de gran importancia para comprender aspectos del ritual funerario Chancay desarrollado en este sitio.

\section{UBICACIÓN Y MEDIO AMBIENTE}

El sitio arqueológico de Cerro Macatón se encuentra ubicado en el valle bajo del río Chancay-Huaral, en la margen derecha del mismo, sobre una pampa ubicada en la parte baja septentrional del cerro Macatón, cerro de gran elevación que alcanza hasta los $614 \mathrm{msnm}$ y que se trata de una estribación andina aislada de grandes dimensiones y asociado a otras estribaciones, constituyéndose en el más elevado del valle bajo y que en periodos prehispánicos tuvo una gran importancia, constituyéndose como una de las paqarinas del antiguo poblador chancayano y que en la parte superior presenta numerosos sitios principalmente ceremoniales.

Políticamente, se encuentra ubicado en la localidad de El Ángel de Macatón, distrito y provincia de Huaral, departamento de Lima. El punto datum del sitio se localiza en las coordenadas UTM: $265200 \mathrm{E}$ y $8729900 \mathrm{~N}$, y a $200 \mathrm{msnm}$. En las últimas dos décadas, un conjunto de invasiones se han posicionado en las laderas bajas orientales del Cerro Macatón, dando origen a asentamientos humanos como Contigo Perú, Nuevo Huaral y El Ángel, siendo este último el que se encuentra asentado sobre parte del sitio arqueológico. Posteriormente, nuevas oleadas de invasiones como el de La Florida, han

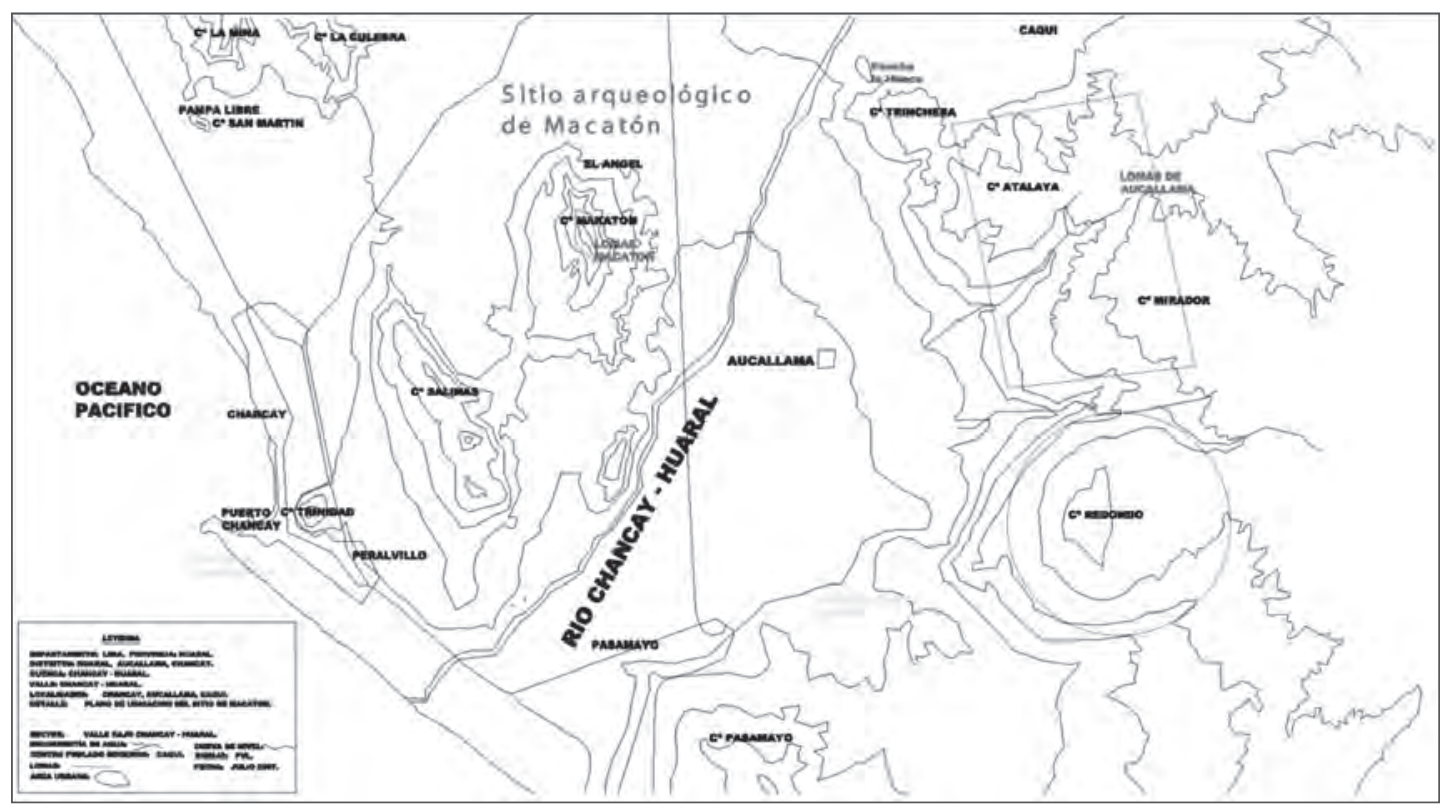

Figura 1. Mapa de ubicación del sitio arqueológico de Macatón. 

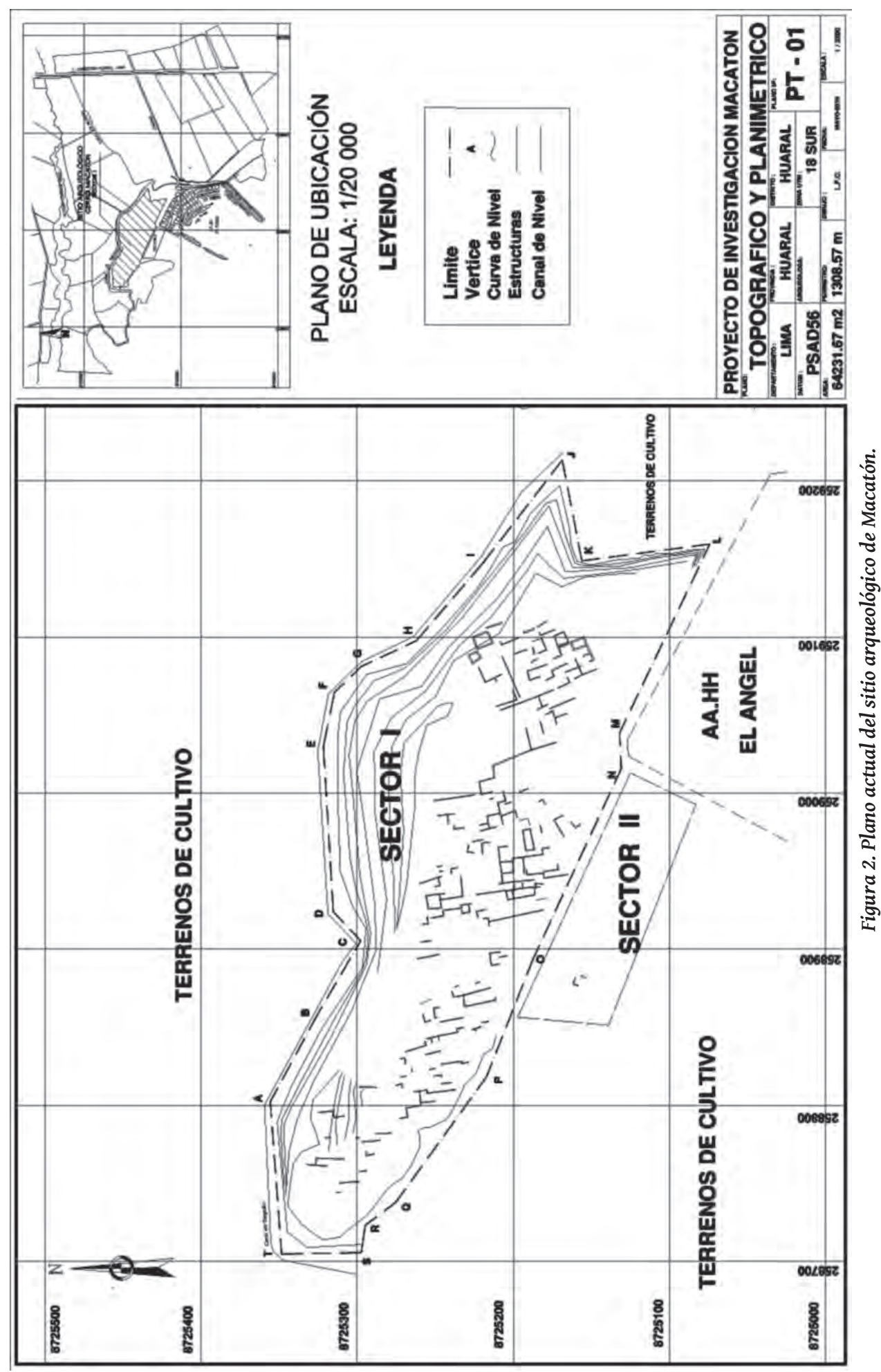
cercado el sitio arqueológico por el lado norte. Pues, cada visita que realizamos al sitio arqueológico, notamos el considerable avance de las viviendas de esteras, madera y hasta en material noble, sin que el INC haga nada, pues además es utilizado como botadero de desmonte, huaqueo y baños públicos. Es lamentable, que un sitio de gran importancia esté destinado a desaparecer. Y por si fuera poco, los terrenos agrícolas del lado occidental lo han cercado en gran medida.

El medio ambiente circundante está conformado por un paisaje de valle costeño, conformado por el territorio plano que conforma el valle y cerros adyacentes de regular altitud, con días soleados en verano y estacionales con ligeras lluvias a modo de garúas en invierno. Las partes medias y altas del Cerro Macatón se convierten en lomas en los meses de invierno.

\section{ANTECEDENTES DE ESTUdio}

Son muy escasas las investigaciones desarrolladas en el sitio de Cerro Macatón, sin embargo, lo que resulta sorprendente, es que el arqueólogo alemán Hans Horkheimer, quien en la primera mitad de la década del 60 del siglo pasado dirigiera la Misión Arqueológica Chancay realizando excavaciones en numerosos sitios del valle entre los que se encontraba Macatón, no mencione en sus pocos artículos publicados, datos sobre este sitio arqueológico.

La labor pionera, que dio a conocer al mundo científico la importancia cultural de Cerro Macatón fue Andrés Mármol Castellanos, investigador que hasta sus últimos días protegió esta zona arqueológica ante las olas de invasiones que se posesionaban de gran parte de ella. Los trabajos de Mármol fueron sistematizados en numerosos artículos que dan cuenta de los materiales que iba descubriendo (Mármol 2007a; 2007b). Una investigadora huaralina reprodujo algunas líneas descritas por el maestro Mármol:

«El año 1940 visité la ciudad tumba de Makatón (Tunkamac) que tenía dos kilómetros de extensión y dividido en tres cementerios: para varones, mujeres y párvulos. De las tumbas se han extraído equipajes funerarios valiosos; ceramios finos, telas preciosas e instrumentos de tejido, de labranza y pesca; objetos de cobre y plata, menajes domésticos y miniaturas de piedra y conchaperlas; medidas de maíz y balanza (Wipe) que servían para el trueque de productos agrarios (sierra y costa), y cuyo centro ferial estaba en Kuilkapampu [...] Un detalle curioso era el retocado de sus tapias que simula ondas de agua visibles bajo la proyección diagonal de los rayos del sol poniente. En aquel entonces, aún quedaban paredes enlucidas con tierras polícromas traídas de La Calera, a saber: ocre o marrón claro, verde claro y crema, conservados en la cara de los muros subterráneos. Makatón ha sido el cerro Pakarina de los viejos pescadores chancayanos y cuya historia es sugerente. En 1956 retorné con el Dr. Amano y costatamos su demolición sistemática y pese a nuestras protestas los tractores han proseguido su obra nefasta [...]». (Buitrón 2007: 351-352).

A partir de 1946 el Dr. Mármol Castellanos inició excavaciones en diferentes sitios arqueológicos del valle, en especial en Cerro Macatón. Identificó e investigó 44 sitios arqueológicos a nivel de la provincia de Huaral. Mármol reportó el hallazgo de numerosos materiales, entre los que figuran: restos de Spondyllus, redes para pesca, pututus, moldes de arcilla, ovillos de hilos, muñecas tejidas, abundantes restos vegetales, instrumentos de metales (martillos, pinzas, tumis, ganchos, entre otros), Instrumentos de madera (principalmente de chonta) referidas a diferentes actividades productivas: pesca (flotadores para redes), textiles (husos, espadines, lizos), agrícolas; telares, prendedores de cabello de madera, abundantes textiles decorados y llanos, sandalias, tejidos plumarios, y abundantes vasijas de diferentes estilos y periodos (Mármol 2007a). Todos estos materiales fueron llevados a la ciudad de Huaral donde en la década del 70 se fundó el Museo Regional Mármol, ubicado en la calle La Estación.

El año 1957 el Dr. Seichi Izumi con la misión japonesa de la Universidad de Tokio, realizó investigaciones en Cerro Macatón. Entre los arqueólogos peruanos que participaron en dicha temporada de campo figuraron Luis G. Lumbreras y Rosa Fung. Sin embargo, Izumi no publicó los resultados de 
esas investigaciones. Rosa Fung Pineda, publicó en 1960 (Fung 1960: 74-129) el reporte del registro y análisis de una tumba que había sido saqueada por huaqueros en el Cerro Macatón. Este trabajo es importante en razón del detalle con que fueron hechas las descripciones. En dicha descripción se puede observar al detalle la cantidad de materiales que se encontraban acompañando al individuo dentro de la estructura funeraria. Fung asocia esta tumba al periodo Chancay último o Negro sobre Blanco, correspondiente al Horizonte Tardío, pues encontró un hoyo de huaqueo a cuyo alrededor se halló gran cantidad de materiales regados sobre la superficie, ubicado a «[...] 200 metros al oeste de la Huaca Macatón.» (Ibid.: 77). La autora llega a la conclusión de que el contexto funerario pertenecía a una persona adulta de sexo masculino decicado a la agricultura pero que en sus tiempos libres se dedicaba a la textilería. Entre los materiales que Fung encontró figuran:

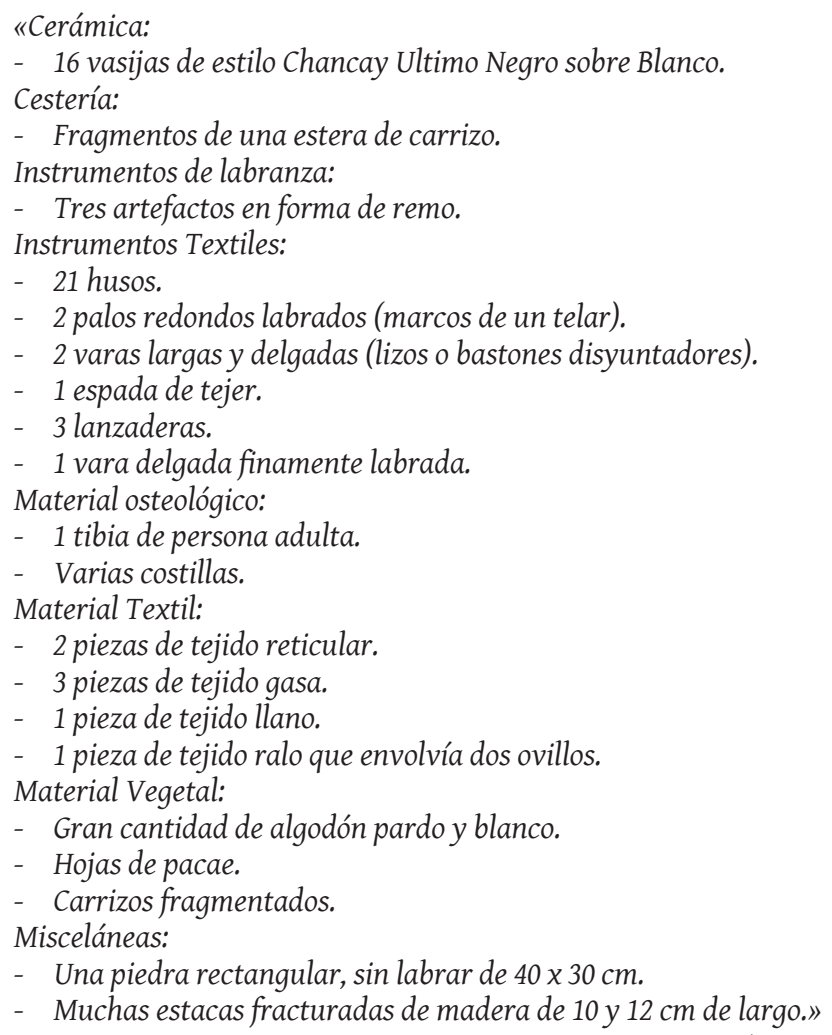

En la primera mitad de la década de 1960, Hans Horkheimer a la dirección de la Misión Arqueológica Chancay, realizó excavaciones en varios sitios del valle, entre estos Lauri, Macatón A y B, Santa Elena, Pisquillo Chico, Pisquillo Grande, y Lumbra; trabajos financiados por la mancomunidad alemana para investigaciones científicas. Entre estos sitios, Horkheimer recuperó más de 100 tumbas (Bonavía 1967), sin embargo, su fallecimiento en 1965 no le permitió publicar los resultados de estas investigaciones tan trascendentales para la arqueología del valle. En los pocos artículos publicados por el investigador antes de su óbito (Horkheimer 1962, 1965, 1970), no menciona al sitio de Macatón, incluso en el trabajo de identificación y bibliografía de importantes sitios prehispánicos del Perú, al describir los sitios del valle Chancay, no lo menciona. Sin embargo, Tarazona describe el hallazgo de una tumba con dos individuos en Macatón, excavados por Hans Horkheimer y la Misión Arqueológica Chancay en el extremo sur del sitio, a partir de la revisión de sus diarios de campo: 
"La tumba es un hoyo cuyos lados van de 2 a $3 \mathrm{~m}$. aproximadamente con una profundidad de $2.60 \mathrm{~m}$ cavada en el terreno natural. Su forma interior no es recta y aunque la boca es mucho más ancha que la base, en la parte media se elaboró un descanso para facilitar la colocación de fardos y ofrendas. Este elemento determina que el fondo sea más estrecho (1.50 $\mathrm{m}$ de largo por $1 \mathrm{~m}$ de ancho).

Esta cavidad sirvió para enterrar a dos personajes de sexo diferentes, cada uno en un fardo funerario. El fardo grande corresponde al cadáver masculino y el menor al femenino. Ambos individuos fueron calculados en mediana edad. Se presume, por la observación de uno de ellos que la posición de los cadáveres era fetal [...].

Lo primero fue colocar los fardos en la parte más baja. Delante y en la base del fardo mayor se dispuso una primera acumulación de vasijas (cántaros, ollas y platos). Luego se cubrieron parcialmente estos restos para poner otra serie de vasijas delante de ambos fardos (cántaros y platos) tapando nuevamente ambos entierros.

Antes de descubrir estos hallazgos se encontró, cercano a la superficie, restos de un pequeño fardo (7) con dos ofrendas de cerámica: figurina y plato. No estamos seguros si estos vestigios formaron parte del mismo evento de enterramiento de aquellos más profundos.

Estos tres bultos funerarios muestran un pésimo estado de conservación. [...] Cada uno de estos "paquetes» estaba constituido por tejidos y totora, también cañas que ayudaron a formar el armazón.

Es interesante resaltar como la cabeza del individuo masculino tenía aún colocado un turbante de lana de colores granate y negro [...] Al interior de este fardo se hallaron cuatro quenas hechas de cañas de hasta $33 \mathrm{~cm}$. De largo y entre los tejidos sencillas telas con representaciones de bandas de colores verde, marrón, ocre. En el fardo menor se encontraron 17 «pushcas» o torteros de madera, pequeños instrumentos textiles utilizados juntamente con las agujas para el hilado de las fibras de algodón o lana.

De esta tumba se obtuvieron 18 vasijas entre las que destacan: un «cuchimilco» (figurina) junto al fardo mas deteriorado, tres «chinas» (cántaros) asociados al fardo grande y una al pequeño, todos dispuestos en cortos momentos y por niveles durante el proceso de enterramiento, el cual debió acompañarse de ciertos ritos de rigor [...]». (Tarazona 1997: 8-9)

En 1974, Santiago Agurto Calvo y Alfredo Sandoval (Calvo y Sandoval 1974) realizaron un catastro e inventario de sitios arqueológicos de todo el valle, realizando una descripción del sitio de Macatón, la cual es muy breve y más se centra en su ubicación y características generales. En el cerro Macatón, Calvo y Sandoval identificaron tres sitios arqueológicos, los cuales no conformaban sitios como unidades aisladas, sino sectores de un extenso complejo arqueológico interrelacionados entre sí. Ellos (Ibid.: s/n) describen un área funeraria («cementerio») muy destruida de una hectárea de extensión, ubicado en la falda norte del cerro Macatón (frente a la hacienda Jesús del Valle), el cual fue definido como Chancay $24 \mathrm{I}-\mathrm{N}^{\circ} 1$ IO 4 . Este sector ubicado en las coordenadas UTM $8725400 \mathrm{~N}$ y $258450 \mathrm{E}$ y fue descrito como: [...] un pequeño cementerio, con tumbas sencillas, es decir simples hoyos en la tierra. Sumamente destruido y con abundantes restos en la superficie.» (Ibid.). El reporte indica el hallazgo en superficie de fragmentería cerámica de estilo Chancay Negro sobre Blanco y de pasta roja. Otro sitio descrito en esta zona por estos investigadores es el que denominaron como Chancay $24 \mathrm{I}-\mathrm{N}^{\circ} 1 \mathrm{JO} 3$, ubicado en las coordenadas $8725200 \mathrm{~N}$ y $260450 \mathrm{E}$, de un área 16 hectáreas, ubicado frente a la Hacienda La Huaca, en la parte baja del cerro Macatón. Este segundo sitio «[...] Se trata de una constelación de pequeños templos, algunos de ellos bastante bien conservados y otros muy destruidos. De algunos de ellos solo quedan vestigios que insinúan la forma original [...]». (Ibid.). La cerámica hallada en superficie es Lauri, Rojo Engobado alisado, Chancay Negro sobre Blanco pasta roja, Chancay Negro sobre Blanco pasta blanca, Inka ordinario, colonial y misceláneos.

De igual forma describen otros sitios como el sitio Chancay 24I N 1 IO3, localizado en las coordenadas $8725200 \mathrm{~N}$ y $259025 \mathrm{E}$, a $175 \mathrm{msnm}$, ubicado en la falda norte del cerro Macatón frente a la Hacienda Jesús del Valle, con un área de 8 ha. Este sitio es descrito como «[...] una población típica, construida en adobón, cortada en dos por el camino que la une con la hacienda La Huaca. En la parte más alta de la quebrada, a 


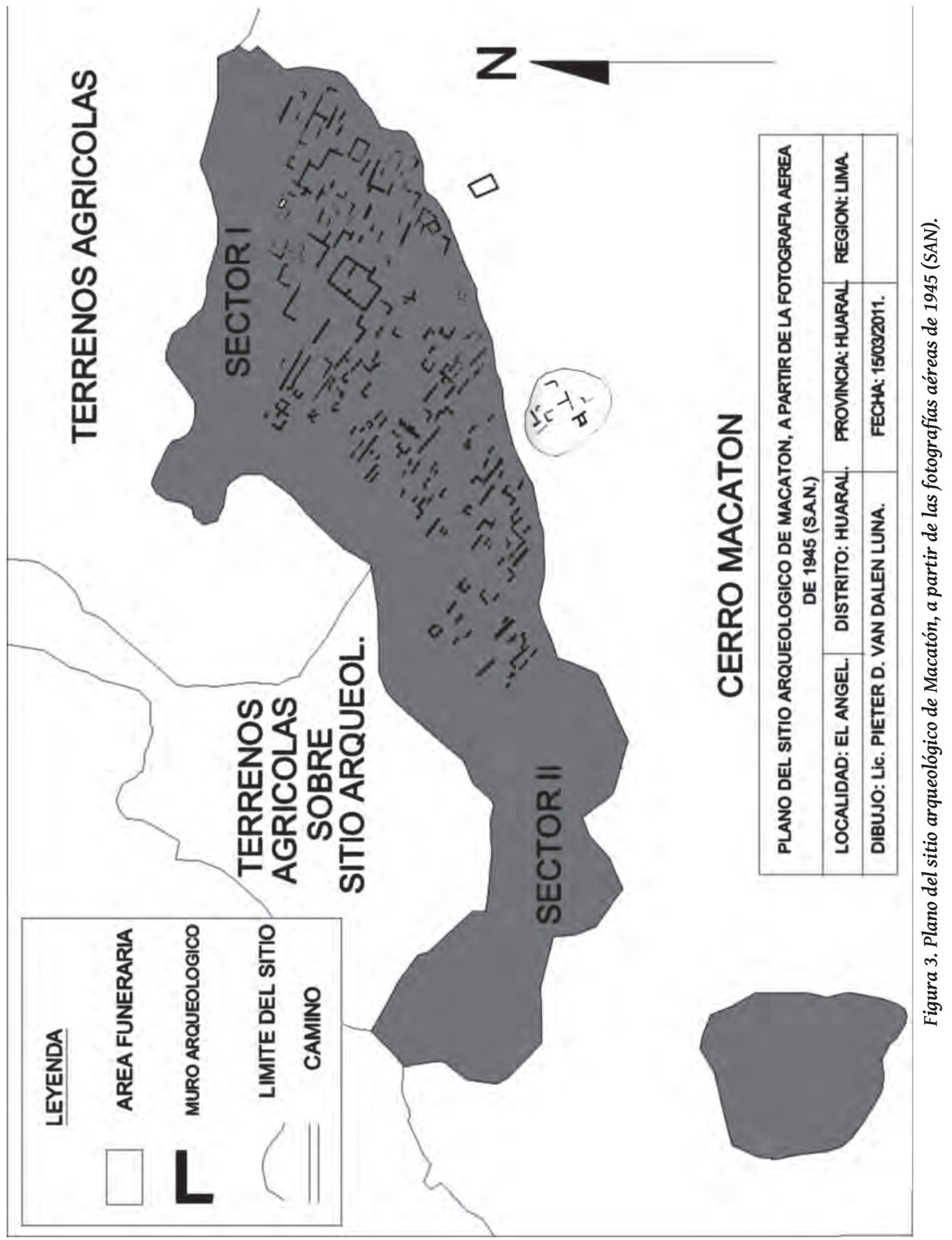


cuyo pie se ubica la población, se encuentra un antiguo cementerio muy destruido. Hay abundancia de cerámica $y$ de restos humanos.» (Ibid.). Se ha encontrado estilos como Lima Tardío, Rojo Pulido, Epigonal Tricolor, Tricolor Geométrico Rojo, Tricolor Geométrico Claro, Rojo Engobado Alisado, Chancay Negro sobre Blanco de pasta roja e Inka Ordinario. Este sitio corresponde al sector que aún se conserva y que es motivo del presente estudio. Es necesario, sin embargo, no obviar el hecho de que los dos autores consideran que el estilo Chancay Negro sobre Blanco corresponde al Horizonte Tardío, infiriendo que este estilo no se elaboró en el Intermedio Tardío o periodos anteriores, propuesta totalmente errada. Además como señalamos, los autores no brindan datos precisos y detallados sobre las características de los sitios.

En la década del 90, el arqueólogo huaralino Javier Tarazona Gamarra realizó investigaciones superficiales intensivas en el valle de Chancay, entre ellas reconocimientos superficiales en Cerro Macatón, como resultado publicó un artículo titulado «Macatón: un viejo pueblo en el valle de Chancay», trabajo publicado en la revista Los especiales de Huacho (Tarazona 1997: 6-10). En este trabajo Tarazona describe muchos componentes arquitectónicos que nosotros, por el avance de la destrucción, ya no pudimos observar. Tarazona divide el sitio en dos sectores: un sector habitacional de 8 ha y uno de cementerio de 1 ha. Sin embargo, el primero corresponde a un sector que presenta además de edificaciones, contextos funerarios. El autor hace referencia que este sector de edificaciones de planta cuadrangular con la mayoría de sus muros con revoque de barro y pintados de crema. Identifica además al Este del sector un área monumental, donde según la organización espacial se habrían realizado actividades públicas de naturaleza urbana, como producción manufacturera (Ibid.: 6). Tarazona, hace referencia que Tello descubrió en 1935 en el interior y debajo de algunos recintos tumbas que fueron selladas con una gruesa capa de barro y luego sirvió como piso al edificio, esto fue corroborado y exponemos en la presente investigación, líneas más adelante. Hace referencia además de una plataforma elevada en el lado noroeste, identificado en la foto aérea de 1945. Se trataría de un sitio donde su población desarrollaba actividades agrícolas y manufactureras. Refirió además, el hallazgo de grafitis sobre los paramentos de tapial, de motivos zoomorfos y antropomorfos; así como

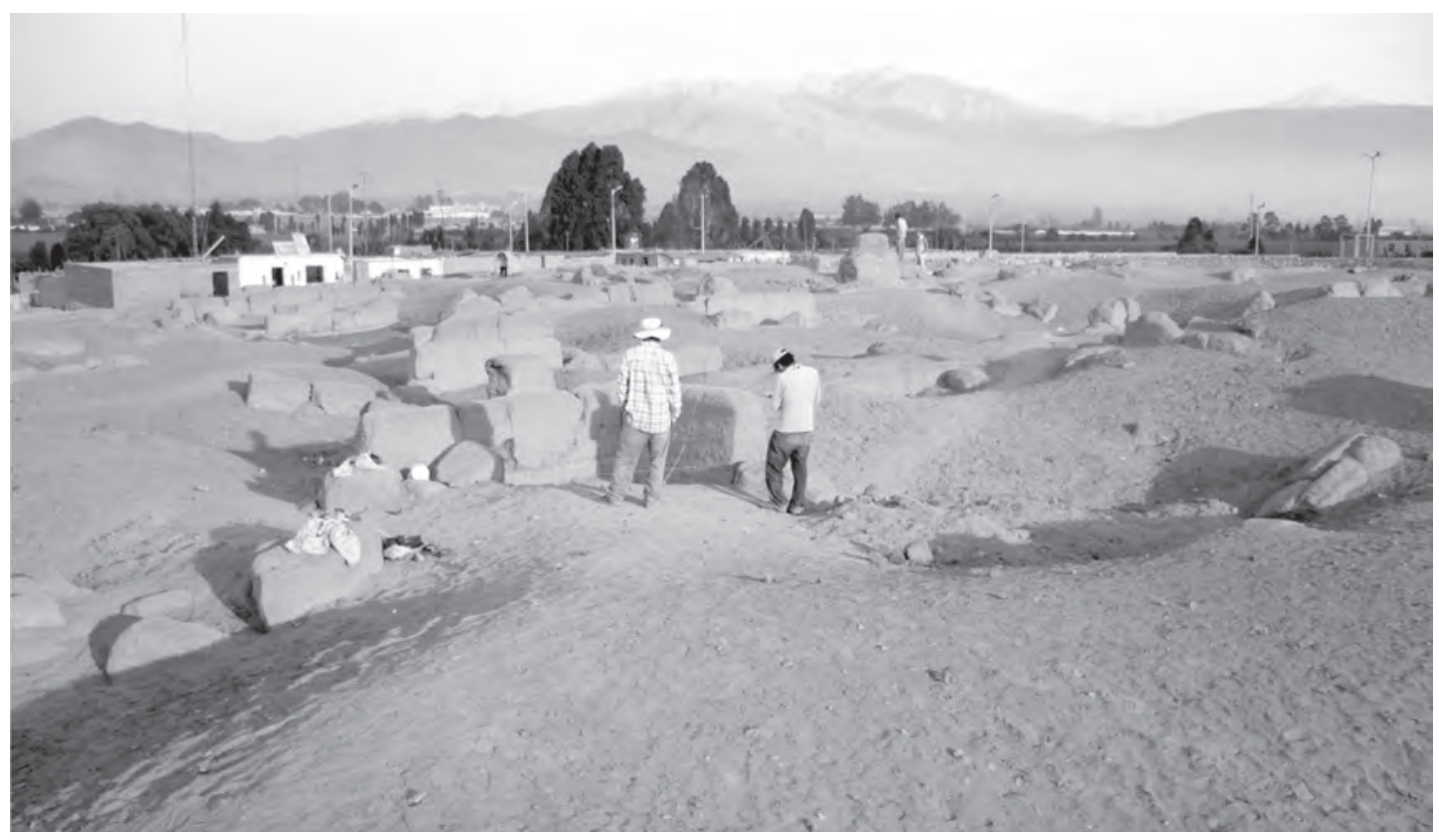

Figura 4. Vista panorámica actual del sitio arqueológico de Macatón, Sector «A». 
en el cementerio halló restos textiles decorados (encajes reticulados, gasas, paños de tela llana con decoración en bandas) y un individuo con el antebrazo y la mano tatuados, al igual que agujas, hilos, canastas de fibra vegetal a modo de costureros, instrumentos de telar, así como numerosos instrumentos agrícolas. Entre el material cerámico que identificó figuran el Chancay, el epigonal, y el Tricolor Geométrico (Ibid:: 10).

Finalmente, en anteriores trabajos, el autor del presente artículo ha hecho referencias sobre el sitio de Macatón, con algunas descripciones de los componentes del sitio (van Dalen 2004, 2008).

\section{OBJETIVOS Y PROBLEMÁTICA DE LA INVESTIGACIÓN}

Desde hace muchos años, casi desde que iniciamos las investigaciones en el valle Chancay, hace una década y media, se tuvo la inquietud de conocer las características de la ocupación Chancay en el sitio de Macatón, definiendo si se trataba solo de un área funeraria o además de un sitio político administrativo Chancay. Además, otra problemática fue la de conocer las características de los contextos funerarios Chancay, así como sus asociaciones. El presente proyecto de investigación se realizó con el objetivo principal de definir las características de los contextos funerarios Chancay en Cerro Macatón, así como la asociación cronológica de los mismos.

Para ello se recuperó información de las cuatro unidades básicas de análisis para la investigación de contextos funerarios, las cuales son: Análisis de la estructura funeraria, análisis del individuo, análisis de las asociaciones y reconstrucción de la ceremonia o ritual funerario.

\section{Componentes Del sitio arqueológico}

Al hablar del sitio de Macatón, nos estamos refiriendo al área funeraria tardía más extensa del valle Chancay-Huaral. Como hemos visto en los antecedentes de estudio, el Cerro Macatón presenta en

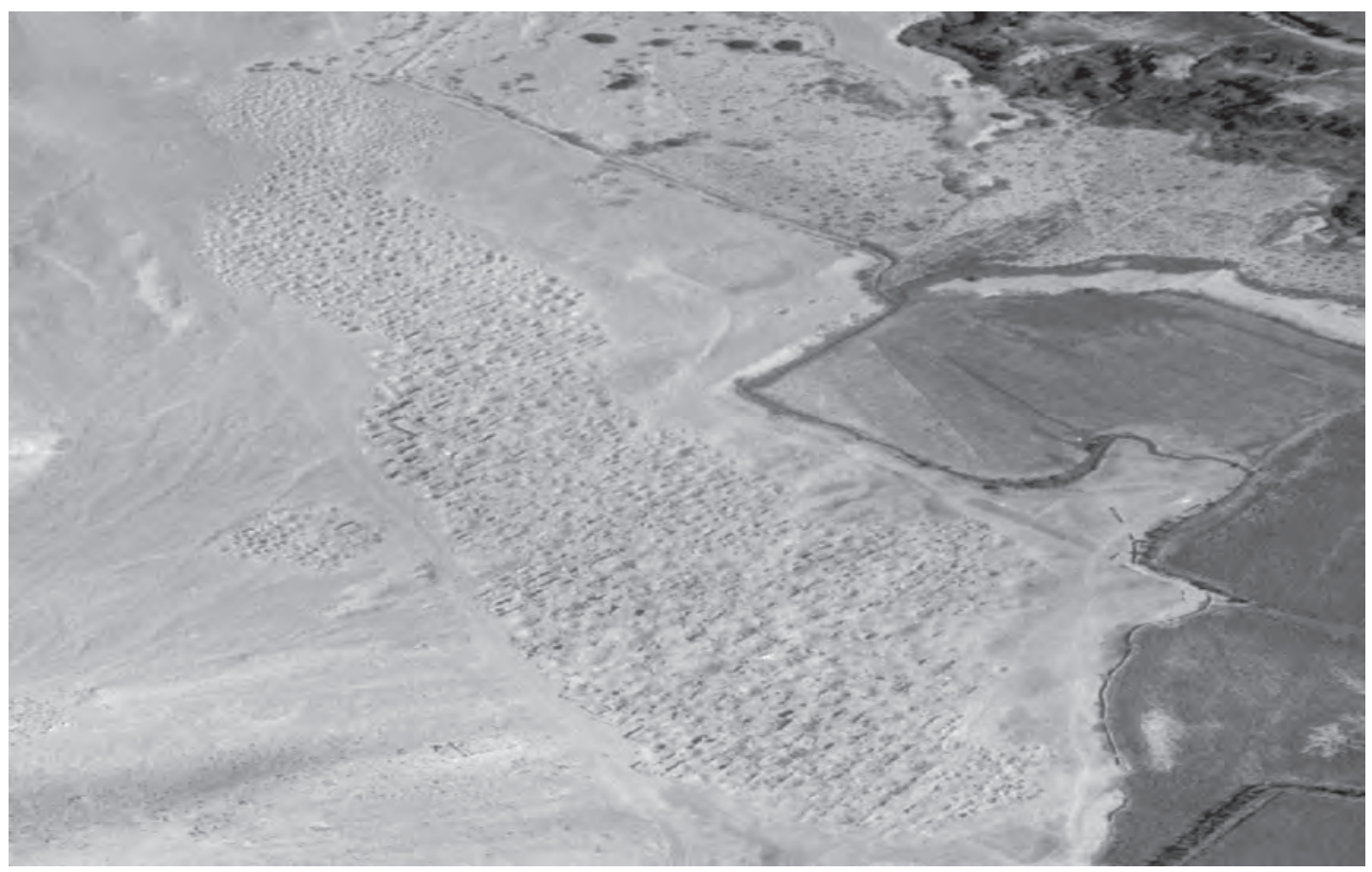

Figura 5. Fotografías aéreas del sitio arqueológico de Macatón de 1945 (SAN), vista de los sectores «A»y «B». 
sus alrededores numerosos sitios arqueológicos de diferentes dimensiones y categorías, de los cuales podríamos afirmar que el sitio de Macatón o Cerro Macatón es el más importante y al cual estaban supeditados los otros sitios cercanos. Es en este sentido que en base a la evidencia material que aún existe en el sitio, y la revisión de las fotografías aéreas de 1982 y la de 1945, podemos definir la división del sitio en los siguientes sectores:

\section{SECTOR «A»}

Este sector es el que más hemos trabajado durante esta temporada y donde hemos realizado las unidades de excavación. Se ubica en el extremo norte de la estribación de Cerro Macatón (conformado por el Cerro Macatón y las pampas bajas ubicadas a sus faldas), limitado por terrenos agrícolas. Este sector se ha reducido a su mínima expresión por haber sido encerrado por asentamientos humanos tales como El Ángel y La Florida. Se trata de una extensa área funeraria de constante ocupación desde el Horizonte Medio hasta el Horizonte Tardío, sobre el cual a finales del Intermedio Tardío y Horizonte Tardío, se edificaron recintos rectangulares a base de tapiales, algunos de forma trapezoidal. Este sector tiene cerca de 150 recintos, algunos interconectados conformando conjuntos residenciales, administrativos y artesanales. La revisión de las fotografías aéreas y la descripción de Tarazona (Tarazona 1997: 10) nos hace referencia que existió en este sector, en su lado noroeste una plataforma elevada, al parecer con rampa, elemento arquitectónico característico Chancay. En las fotos aéreas de 1945 se aprecia hacia el lado sur del sector, en la primera elevación ocupada hoy por el centro poblado El Ángel, un conjunto arquitectónico aislado del resto del sector, conformado por un mínimo de ocho recintos de planta rectangular y cuadrangular, aglutinados entre sí, edificados aparentemente en tapiales, lo que conformaría al parecer un área residencial de élite donde habría residido el curaca local. Tarazona refiere que el área del sector ubicado hacia el lado este podría ser un área de producción manufacturera (Ibid.: 6). Hacia el lado sureste, sobre al estribación ocupada por el centro poblado El Ángel, hay otro conjunto conformado por un mínimo de dos recintos cuadrangulares contiguos.

La mayoría de los muros están edificados en tapiales, mediante la técnica de paños murarios, colocando bloques de manera consecutiva uno sobre otro, dejando entre ambos una capa de barro. Los muros tienen, por lo general, mayor ancho en la parte baja y son más delgados en la parte superior, con un promedio de entre 0,70 y $1 \mathrm{~m}$ de grosor. Las esquinas por lo general son adosadas. La estrategia constructiva de este sector, presupone la edificación de grandes espacios rectangulares (muros primarios), en cuyo interior se edifican luego subdivisiones internas de planta cuadrangular o rectangular (muros secundarios), interconectados mediante pasadizos internos. Por su parte los conjuntos se interconectan mediante calles. Hay un mínimo de edificaciones realizadas con adobes, dispuestos en los muros principalmente a soga, aunque hay algunos muros que presentan en cada hilada cada cuatro o cinco adobes a soga, uno a tizón. La altura promedio de los muros estaba entre 2,50 a $3 \mathrm{~m}$ de alto. La mayoría de muros presentan tarrajeo, y sobre estos decoración muraria. Hay muros que presentan grafitis sobre sus paramentos, y en la mayoría presentaban pintura blanca, hecho con un material blanquecino parecido al estuco. Durante las excavaciones se pudo observar que en aquellas áreas de los muros que se encontraban expuestos al medio ambiente por el huaqueo $u$ otros factores, no se notaba esta pintura, pero al excavar aquellas áreas contiguas a los paramentos enterrados, se podía notar las características de los recubrimientos, siendo esta una capa muy delgada y sensible al tacto. Los grafitis son, por lo general, figuras de aves, felinos o peces. Hay muros que presentan el basamento hecho con piedras grandes, sobre el cual se colocaba el primer bloque de tapial. La dimensión de los recintos era variada, desde pequeños hasta grandes. 


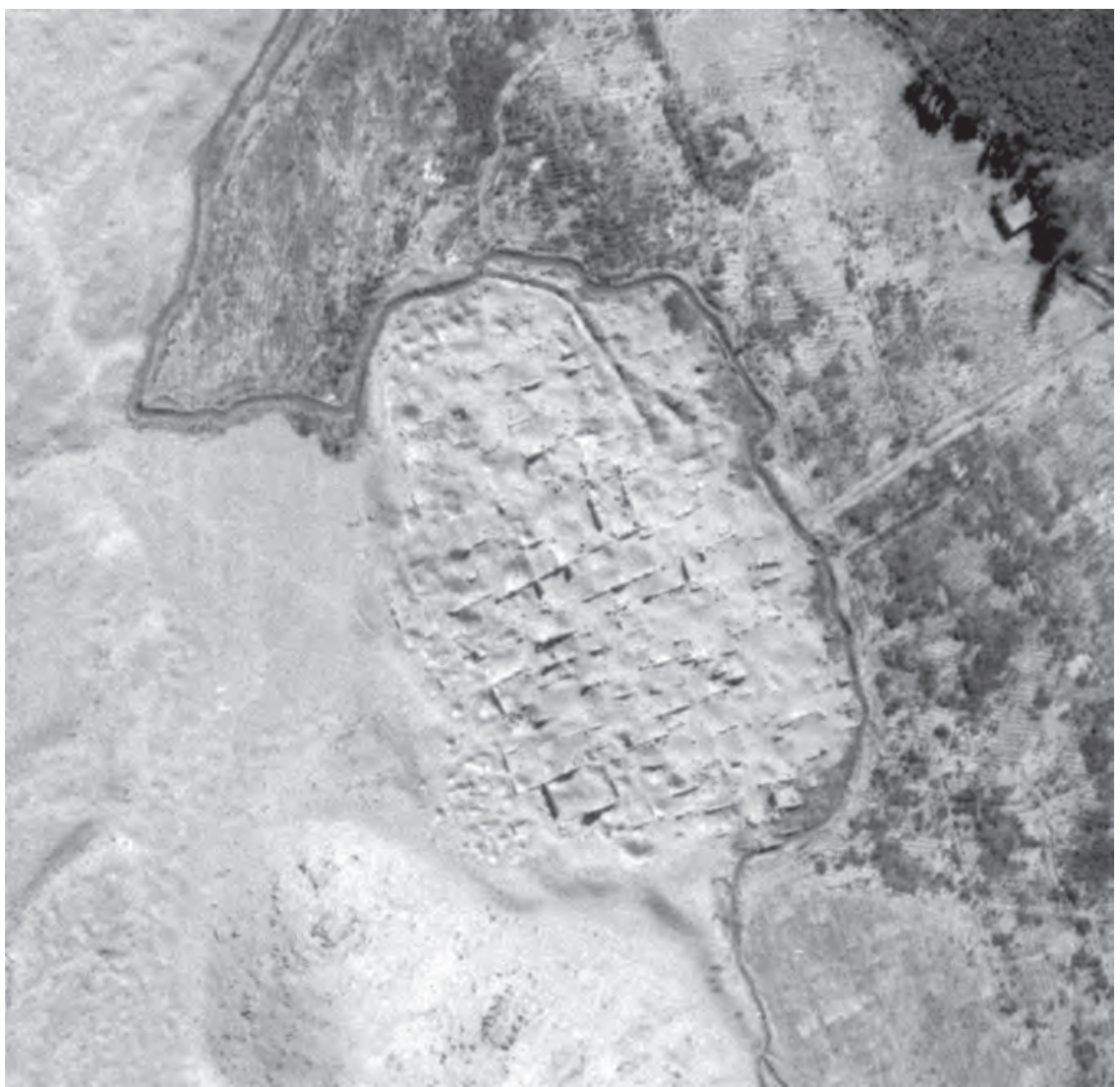

Figura 6. Fotografía aérea del sitio arqueológico de Macatón de 1945 (SAN), con el sector «C».

Se ha encontrado en la superficie abundante material cultural, tales como fragmentería cerámica de diversos estilos, locales y foráneos, lo que evidencia las interacciones interregionales de las poblaciones locales chancayanas con otras regiones lejanas. Entre estos estilos tenemos el Teatino, Huaura, Pativilca-Supe, Pampa de Animas del Horizonte Medio; Chancay, Lauri Impreso, Huacho, del Intermedio tardío; Inca local, Chimú-Inca, Chancay del Tawantinsuyu; y Colonial Temprano incluyendo un Chancay Colonial del periodo de transición Tawantinsuyu-Colonial. Se ha identificado además retazos de tejidos elaborados en diferentes materiales como algodón, lana de camélidos, fibras vegetales y cabellos humanos; y hechos en diversas técnicas, como tapices, redes, gasas, tejidos llanos, entre otros. Se observa además numerosos restos óseos humanos, restos de madera, restos malacológicos, soguillas, restos óseos animales, algunos artefactos líticos, entre otros. Estos materiales están entremezclados con basura moderna, desmonte, periódicos, basura quemada, vidrios, ropa actual, entre otros. Justamente antes de desarrollar las excavaciones y al observar que la población de los centros poblados modernos aledaños utilizaban el sitio como letrina, botadero de desmonte o de basura, decidimos realizar la limpieza mediante un trabajo de concientización para lo cual se contrató a 80 personas de estas localidades por un periodo de cinco semanas, para realizar la limpieza de la basura moderna que se hallaba sobre el sitio arqueológico previa capacitación y concientización cultural, actividades que fueron detenidas por el Instituto Nacional de Cultura. Hoy, tres años después de las excavaciones, el sitio se encuentra más destruido, 
sin que el Ministerio de Cultura haga algo por impedirlo, pues el sitio en su totalidad está próximo a desaparecer en los próximos años.

En la actualidad, el 65\% de recintos se encuentran destruidos, mientras que el resto está en proceso de destrucción. El huaqueo y el avance de las invasiones en sus alrededores, son los principales agentes de deterioro de las edificaciones, las que provocaron la remoción de grandes cantidades de arena con las cuales algunos muros que aun quedaron se encuentran cubiertos hasta ser enterrados.

\section{SECTOR «B»}

Este sector se encuentra ubicado hacia el suroeste del sector A y abarca casi la quinta parte de la extensión del anterior. Está conformado por un área funeraria (se puede pensar que es la extensión de la anterior), la cual se extiende hasta los primeros taludes que se elevan hacia los cerros bajos de arena de Macatón. Gran parte de este sector ha desaparecido por la invasión del centro poblado El Ángel y el avance de los terrenos agrícolas circundantes. Se aprecia en la superficie actual numerosos hoyos de huaqueo, con abundante material cultural regado en superficie. No presenta edificaciones, salvo algunos muros de adobe que conformaban cámaras funerarias Chancay. Se observa en superficie los mismos materiales culturales que en el sector anterior.

\section{SECTOR «C»}

El sector «C» se encuentra en la quebrada ubicada en el lado posterior al sector «A», hoy ocupada por asentamiento humano Nuevo Huaral. Es un sector pequeño, conformado por un área funeraria simple, en la cual los contextos funerarios se depositan en el interior de pequeñas matrices o fosas cavadas en el terreno cascajoso. Este sector se ubica en la parte alta de la mencionada quebrada.

En las fotografías aéreas de 1945 se observa un sitio aislado, ubicado hacia el lado oriental del sector "A», a casi uno o dos kilómetros de distancia, frente a la antigua hacienda La Huaca, en el extremo de los terrenos que hoy corresponden al centro poblado Contigo Perú. Se trata de un sitio con unidades arquitectónicas medianas, de planta cuadrangular y rectangular, aglutinadas e interconectadas mediante pasadizos. Al parecer, este sitio sería el mismo que Agurto Calvo y Sandoval denominaron como Chancay 24I-N 1 JO3, cuya descripción citamos en los antecedentes de estudio.

Parece propicia la oportunidad para mencionar que en el mes de setiembre del año 2007 realizamos una prospección en la parte superior del Cerro Macatón, en cuya cima principal (0257915E, 8723563N, 614 msnm, Sistema WGS-84), en medio de los afloramientos rocosos existentes, se halló abundante fragmentería cerámica de estilo predominantemente Chancay, en medio de habitáculos de aparente función ceremonial, emplazados sobre aterrazamientos continuos. Es conocido que este cerro se constituía en el apu tutelar del valle, de gran importancia religiosa en la cultura Chancay.

\section{Metodos y TÉCNICAS DE EXCAVACIÓN}

Los métodos de excavación utilizados en el trabajo de campo fueron por unidades restringidas de 2 x 2 $\mathrm{m}$, ubicadas generalmente en las esquinas de algunos recintos visibles en superficie. En algunos casos se realizóampliaciones para tener un mejor panorama de los contextos, esto por la naturaleza de la capa arenosa, muy deleznable. La definición de capas fue por letras, excavando a mano siguiendo la deposición de las capas naturales y culturales. 


\section{COMPOSICIÓN ESTRATIGRÁFICA IDENTIFICADA EN LA INVESTIGACIÓN}

La composición estratigráfica identificada en el sitio de Macatón durante las excavaciones, revelan una similar secuencia de capas en casi todo el sitio. Esta secuencia es la siguiente (Tabla 1):

\begin{tabular}{|c|c|c|c|}
\hline Capa & Grosor (promedio) & Color & Características \\
\hline Superficial & 0,03-0,10 m. & Gris claro. & $\begin{array}{l}\text { Tierra suelta mezclada con material cultura } \\
\text { disperso y basura moderna. }\end{array}$ \\
\hline A & $1,80 \mathrm{~m}$. & Gris claro. & $\begin{array}{l}\text { Arena fina entremezclada con gravilla y } \\
\text { escombros de muros, así como material } \\
\text { cultural disturbado. }\end{array}$ \\
\hline B & $0,40-0,65 \mathrm{~m}$ & $\begin{array}{l}\text { De marrón } \\
\text { claro a beige. }\end{array}$ & $\begin{array}{l}\text { Arena fina entremezclada con gravilla } \\
\text { o cascajo, de consistencia suelta, } \\
\text { entremezclado con material cultural, } \\
\text { asociado en algunas unidades a pisos. }\end{array}$ \\
\hline C & 0,65-1,92 m. & $\begin{array}{l}\text { De beige a } \\
\text { gris. }\end{array}$ & $\begin{array}{l}\text { Arena entremezclada en regular proporción } \\
\text { con cascajo, de naturaleza compacta, con } \\
\text { escaso material cultural. En la unidad } 4 \text { no } \\
\text { aparece. }\end{array}$ \\
\hline $\mathrm{D}$ & Estéril & Beige. & Arena con cascajo de naturaleza compacta. \\
\hline
\end{tabular}

En algunas unidades aparecen pequeñas capas intermedias, producto del huaqueo, o de la edificación e intrusión de contextos funerarios.

\section{UNIDADES DE EXCAVACIÓN Y CONTEXTOS FUNERARIOS}

Como se señaló líneas arriba se realizó la excavación de cinco unidades de excavación restringidos, de 2 x 2 m, los cuales fueron ampliados para una mejor definición de los contextos funerarios. Las unidades excavadas y su composición estratigráfica fueron las siguientes:

\section{UNIDAD 1}

Se encuentra localizada en el sector "A», teniendo como centro las coordenadas UTM: $8724798 \mathrm{~N}$ y $258861 \mathrm{E}$, a una altitud de $230 \mathrm{msnm}$. Es de 2 x $2 \mathrm{~m}$. Se encuentra ubicada en el interior de un recinto de planta rectangular (de $6 \times 4 \mathrm{~m}$ ), en la esquina noroeste del
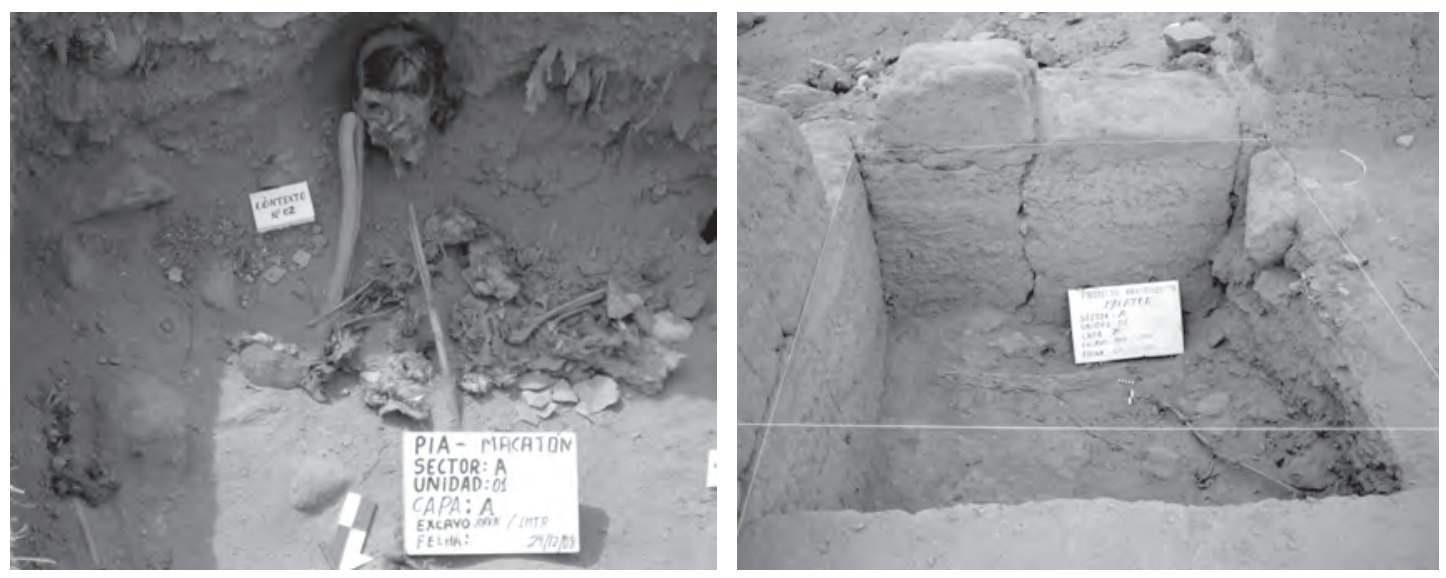

Figura 7. (Izquierda): Vista del Contexto 2, Unidad 1. Figura 8 (derecha): Vista de la Capa B, Unidad 1. 
mismo, junto a sus muros divisorios (MI y MII). El muro I, ubicado en el lado oeste de la unidad (de disposición norte-sur), se caracteriza por estar edificado en tapial edificado mediante la técnica de paños murarios, con un basamento de rocas medianas emplazado sobre una compactación de tierra. Este muro se encuentra muy deteriorado. La superficie muraria presenta enlucido de color blanco de $2 \mathrm{~mm}$ de grosor. Este muro tiene 2,50 $\mathrm{m}$ de alto y 0,60 $\mathrm{m}$ de grosor. Por su parte, el muro II, es de características similares al anterior, se ubica en el lado norte de la unidad (de disposición este-oeste), tiene $2 \mathrm{~m}$ de alto y 0,60 $\mathrm{m}$ de grosor. El muro II se encuentra adosado al muro I. La secuencia estratigráfica identificada en esta unidad es la siguiente:

Capa S: Es de similares características descritas líneas arriba.

Capa «A»: Capa disturbada de color gris, compuesta por arena fina entremezclada con gravilla, escombros de los muros colapsados (Muro II) y basura moderna. El grosor de la capa va desde los 0,68 a 0,89 m. Se identificó material cerámico fragmentado así como textiles deteriorados, material botánico, óseos humanos, material malacológico, material orgánico animal y vegetal.

Contexto № 1 . Se registró a una profundidad de 1,64 m, cerca del muro oeste (a 0,20 $\mathrm{m}$ de distancia) y a $0,70 \mathrm{~m}$ de distancia del perfil sur. Se trata de un contexto funerario humano disturbado, entre cuyos elementos se logró encontrar: huesos largos humanos entrecruzados y atados por una soguilla, cubiertos por ramas delgadas y hojas secas. Junto a estos se halló costillas de camélido, y cerámica fragmentada diagnóstica de estilo Chancay, así como textiles deteriorados y material botánico (algodón). No fue posible definir la matriz funeraria por el alto grado de destrucción. Es posible que se encuentre asociado al Contexto № 2 ya que se encuentra muy próximo a este. El área de este contexto es de 0,65 x 0,60 m.

Contexto № 2. Se encontró a una profundidad de 1,68 m al Sur de la unidad, a 0,80 $\mathrm{m}$ del Muro I y a 1,40 m de distancia del Muro II. Se encuentra disturbado. Los componentes culturales hallados son textiles fragmentados, ramas de árboles, material orgánico animal, una pierna de camélido (con carne, piel y pelaje color amarillento), fragmentos de cerámica estilo Chancay y un cráneo humano de sexo (conservaba aún el cuero cabelludo, dientes en el maxilar, un pedazo de lana de camélido que cubría la parte izquierda del frontal), sin mandíbula.

Contexto № 3. Se encuentra junto al Muro II a 0,80 m de distancia del Muro I, a una profundidad de $1,77 \mathrm{~m}$ de la cota. Se encontró también disturbado, hallándose un cráneo humano incompleto (solo tenía el hueso frontal) de sexo, colocado en posición invertida, junto a otros óseos humanos fragmentados, ramas delgadas, cáscaras de pacae y fragmentos de cerámica estilo Chancay. El contexto se halló debajo de una gruesa capa de escombro de tapial caído del Muro II.

Capa «B»: Es de características similares a la anterior, aunque sin escombros de tapial, pero separada de la anterior por un delgado lente de gravilla. El grosor de la capa es de 0,75 a 0,90 m. Es de naturaleza semicompacta y de color gris claro. Se encontró entremezclada con material cerámico fragmentado, así como textiles, botánico, óseos humanos y animales fragmentados, malacológico, orgánico animal y vegetal.

Piso № 1: Abarca casi la mitad oeste de la unidad, presentándose deteriorado en la otra mitad, elaborado de tierra, de naturaleza compacta, color marrón oscuro, presenta revoque en los Muros I y II, tiene 0,07 $\mathrm{m}$ de grosor.

Contexto № 4: Se encuentra ubicado en el lado noroeste de la unidad, a 0,50 m del Muro I y a 0,30 $\mathrm{m}$ del Muro II, a una profundidad de 1,84 $\mathrm{m}$ de la cota, por debajo del 
piso № 1 en una zona rota intencionalmente (de forma cuadrangular de 0,70 x 0,45 m) y donde se introduce la capa B. Se halló un cráneo humano deteriorado en posición horizontal mirando al suelo, disturbado y sin asociarse a algún otro elemento.

Piso № 2: Se ubica inmediatamente bajo el piso № 1, y cubre la misma área que la anterior (lado oeste de la unidad), de color gris claro y compuesto por arena fina semicompacta. Existe una gran ruptura de forma cuadrangular de 0,38 x 0,25 $\mathrm{m}$ en la esquina suroeste. El grosor promedio del piso es de 0,05 $\mathrm{m}$, con un adelgazamiento que va de Norte a Sur.

Capa «C»: Capa de arena entremezclada con grava y algunos terrones dispersos, de color marrón claro y naturaleza suelta en el lado este pero muy compacta al Oeste. El grosor de la capa es de 0,40 a 0,50 m. Se registró en el interior de esta capa material cerámico fragmentado, así como textiles, botánico, óseos humanos y animales, malacológico, orgánico animal y vegetal.

Contexto $\mathrm{N}^{\circ}$ 5: Se ubica en la esquina suroeste de la unidad, a 0,30 $\mathrm{m}$ de la esquina, a una profundidad de 2,12 $\mathrm{m}$ desde la cota. El contexto está conformado por cuatro ceramios alineados de estilo Chancay, orientados hacia el Norte. Las vasijas estaba conformadas por dos vasos tipo keros sin decoración de pasta roja, sobre el kero de mayor tamaño ubicado al Norte se halló un plato de engobe crema en posición invertida, mientras que sobre el kero de menores dimensiones y ubicado al lado sur se halló un cuenco pequeño de engobe crema en posición invertida. Asociados hacia el lado norte se halló un hueso temporal y un frontal, así como una costilla y fragmentería cerámica de estilo Chancay.

Contexto № 6: Se encuentra ubicado a 0,50 m del Muro II y por debajo del Muro I, a una profundidad de 2,60 de la cota. El contexto comprende cinco vasijas alineadas de manera consecutiva y orientados al Norte. Las dos primeras son cantaros Chancay Negro sobre Blanco, de tamaño grande. La primera tiene decoración de motivos geométricos cuadrangulares por debajo del borde y en el asa; mientras que la segunda tiene decoración pictórica en todo el cuerpo, así como dos apéndices con forma de cabeza de felino, por debajo del cuello. Sobre estos dos cantaros, en la boca de cada uno de ellos, se encontraban dos cuencos pequeños con decoración de bandas negras por debajo del labio, estos colocados en posición invertida, como una tapa de la boca de los cantaros. La última vasija es una olla sin decoración ubicada junto a los cántaros, con muestras de hollín, registrándose en su interior, material orgánico animal (un pequeño cuy disecado). Cabe la posibilidad que excavando más al Oeste (fuera de la unidad) se identifique un contexto funerario.

Contexto № 7: Se halló en el lado oriental de la unidad, extendiéndose en la mitad de la unidad de sur a norte, y por debajo del Muro II. Se halló a una profundidad de 2,62 $\mathrm{m}$ al Norte y 2,76 $\mathrm{m}$ al Sur. Se trata de un contexto funerario múltiple, disturbado, conformado por varios cráneos fragmentados, huesos largos como tibia y fémur, rodeados de hojas secas, ramas entrecruzadas, cerámica estilo Chancay, soguillas y telas que conformaban un fardo funerario de gran tamaño y con textiles decorados. El contexto se encuentra orientado hacia el Norte, aunque es difícil determinar su posición debido a que ha sido disturbado.

Piso № 3: Se encuentra por debajo de la capa «C», no presenta revoque a los muros. Solo se encontró una pequeña porción en el lado oeste. Es de textura dura y está compuesta por arena y gravilla muy fina pero muy compactada. Posee un grosor de $0,05 \mathrm{~m}$. 
Capa «D»: Esta capa antecede a la capa estéril, los componentes culturales ya no se encuentran tan dispersos, salvo algunos fragmentos cerámicos que se encontraron en la superficie de la capa. La capa está formada por arena compactada entremezclada con gravilla en regular proporción, de naturaleza compacta, color beige, y un grosor de 0,60 a $0,65 \mathrm{~m}$.
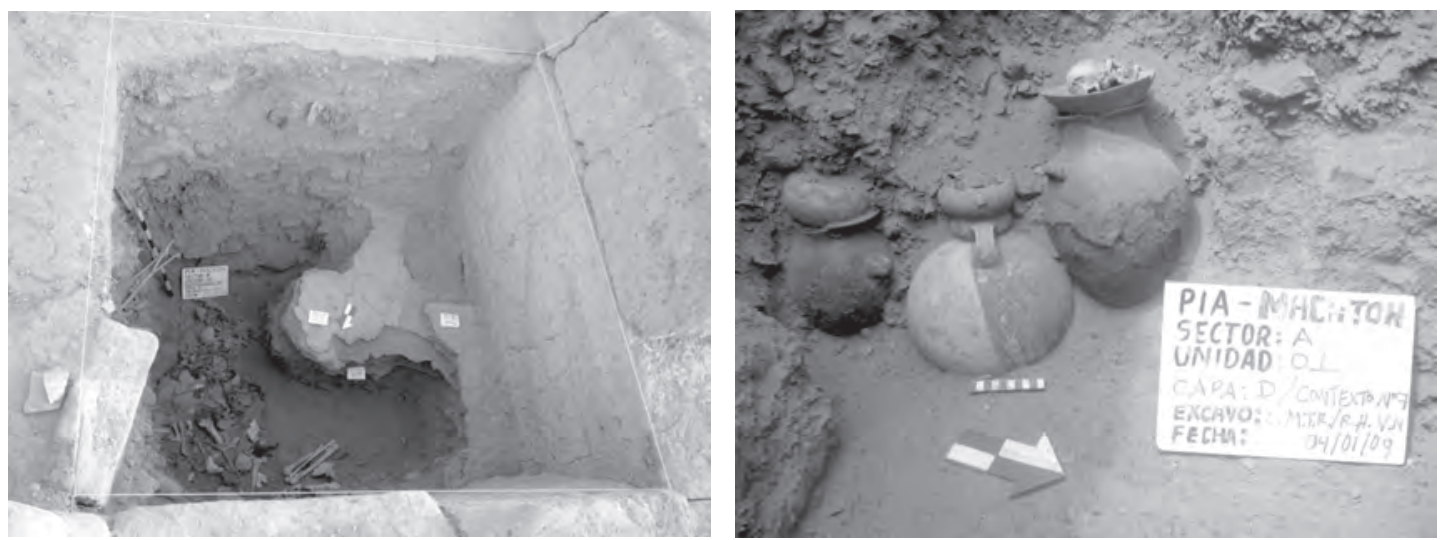

Figura 9 (Izquierda): Piso 2 roto, y al fondo el contexto 7, unidad 1. Figura 10 (derecha): Contexto 8, unidad 1.

Contexto № 8: Se encuentra ubicado cerca de la esquina suroeste a $12 \mathrm{~cm}$ del Muro $\mathrm{I}$, a una profundidad promedio de $2,90 \mathrm{~m}$ desde la cota. El contexto comprende seis vasijas completas y algunos fragmentos rotos de estilo Chancay, asociados a restos óseos animales. El contexto se encuentra alineado hacia el Norte de forma consecutiva. La primera vasija es un cántaro grande de estilo Chancay sin decoración (posiblemente de uso doméstico), en cuyo interior se halló huesos y pelaje de cuy; y sobre este cántaro, a modo de tapa, se encontraba un plato extendido, el cual contenía en su interior el cráneo pequeño de un cánido con residuos de su pelaje. La segunda vasija, también un cántaro, de grandes dimensiones, posee decoración Negro sobre Blanco, y de igual manera en su boca se halló un cuenco Negro sobre Blanco. Junto a este segundo cántaro, al Sur, hay una olla de cuello corto y cubierta de hollín, de tamaño mediano y sin decoración, en cuyo interior se halló pescado seco (anchoveta). Sobre esta olla se encontró un cuenco pequeño decorado Negro sobre Blanco con motivos geométricos y en zigzag.

Capa «E»: Corresponde a la capa estéril, formada por arena entremezclada en igual proporción con cascajos.

\section{UNIDAD 2}

Se encuentra localizada en el sector «A», teniendo como centroide las coordenadas UTM: $8724812 \mathrm{~N}$ y $258822 \mathrm{E}$, a una altitud de $225 \mathrm{msnm}$. Es de 2 x $2 \mathrm{~m}$. Se encuentra ubicada en el interior de un recinto de planta rectangular (de 7,60 x 4,20 m), en la esquina sureste del mismo, junto a sus muros divisorios (M1 y M2). El Muro I, de tapial, está ubicado en el lado oriental de la unidad (de disposición norte-sur), fue elaborado sobre una capa de relleno, sobre la cual fue edificado sin un basamento elaborado. Tiene una altitud de $1,80 \mathrm{~m}$, un ancho de 0,70 $\mathrm{m}$ en la base y 0,60 $\mathrm{m}$ en la parte superior. La superficie muraria presenta enlucido de color blanco de $3 \mathrm{~mm}$ de grosor. El Muro II, es de características similares al anterior, ubicado en el lado sur de la unidad (de disposición este-oeste), tiene 1,80 $\mathrm{m}$ de alto y 0,60 $\mathrm{m}$ de grosor. Cuando se llegó a la Capa D, se hizo una ampliación de la 
unidad hacia el lado oeste, lo mismo que una segunda ampliación de 0,50 m hacia el lado norte, para una mejor definición de los contextos hallados. La secuencia estratigráfica identificada en esta unidad es la siguiente:

Capa «S»: De similares características descritas líneas arriba.

Capa «A»: Capa de 0,08 a 0,15 m de grosor, de color marrón claro, formada por arena fina de naturaleza semicompacta, entremezclada con fragmentería cerámica, restos orgánicos humanos y basura moderna.

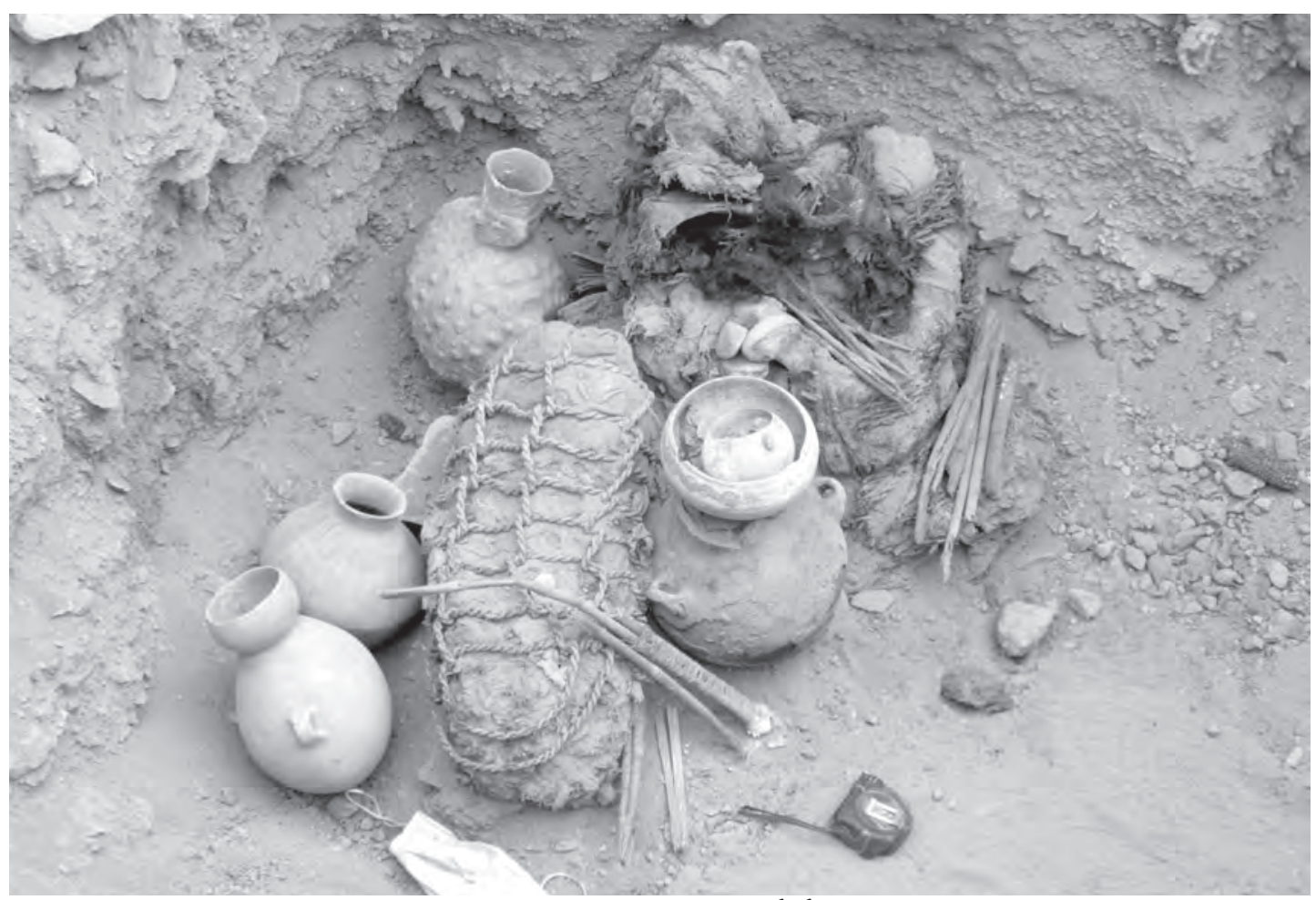

Figura 11: Contexto 9, unidad 3.
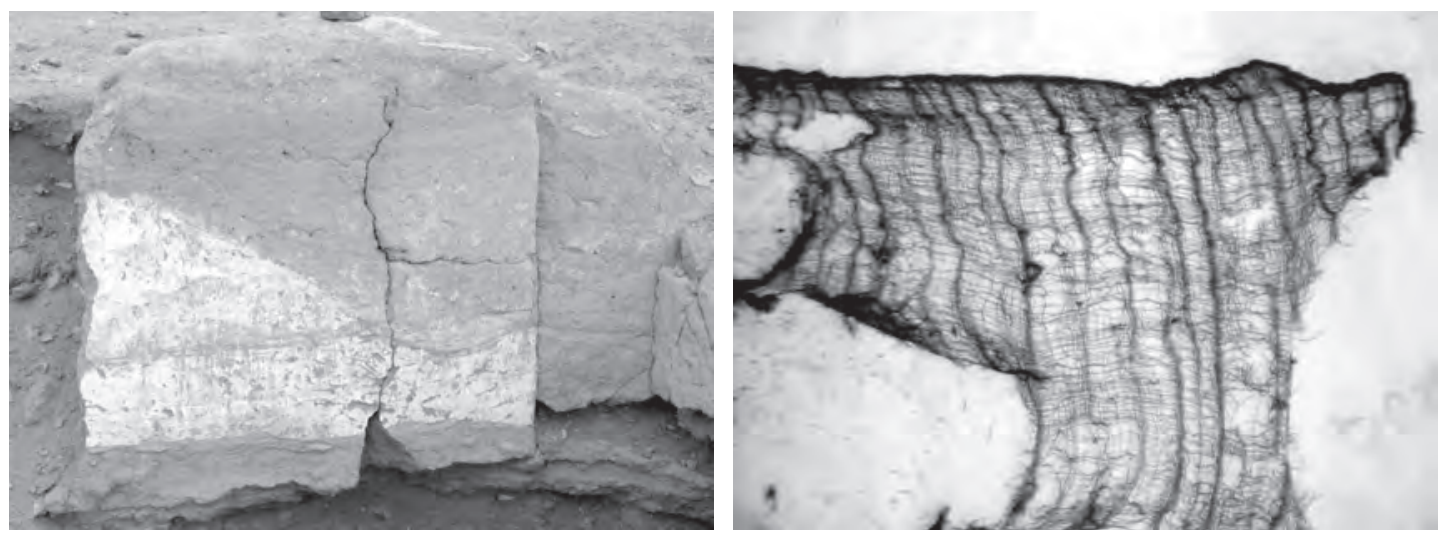

Figura 12 (Izquierda): Muro con enlucido crema en mal estado de conservación, la parte descolorida es la que ha estado a la intemperie. Figura 13 (derecha): Gasa Chancay elaborada con cabellos humanos de color castaño oscuro. 
Capa «B»: Capa de tierra color gris oscuro, entremezclada con piedras medianas y gravilla. El grosor de la capa es de 0,25 m. Casi finalizando la excavación de la capa se halló el cuello de un cántaro tipo "china», así como una copita en miniatura de forma cónica. Se halló en el interior de la capa fragmentería cerámica Chancay, restos malacológicos y restos orgánicos humanos y de animales; así como algunos escombros de tapial.

Capa «C»: Capa de arena fina de color beige, de 0,80 $\mathrm{m}$ de grosor, entremezclada con pequeñas piedras. Esta capa, de naturaleza disturbada, está intruyéndose en dos pisos rotos, el primero (Piso 1) a 0,20 m al interior de esta capa (de naturaleza compacta y 0,04 $\mathrm{m}$ de grosor y revoque al muro II) y el segundo a 0,30 $\mathrm{m}$ (Piso 2), de naturaleza compacta, de 0,025 m de grosor, con revoque al muro I. En la ampliación oeste se halló escombros de tapiales.

Capa «D»: Capa de arena de color gris, entremezclada con cascajo, de naturaleza compacta. Tiene 0,63 $\mathrm{m}$ de grosor, variando en diferentes puntos de la unidad por la naturaleza del terreno.

Piso 3: Se encuentra muy destruida, de naturaleza compacta, de 0,03 $\mathrm{m}$ de grosor. Se ubica a 1,64 $\mathrm{m}$ al interior de la cota.

Piso 4: De naturaleza compacta formado por tierra entremezclada con algunos elementos como cascajo pequeño, entre otros. Tiene 0,05 $\mathrm{m}$ de grosor. Este piso se encuentra cubriendo el relleno (Capa E) donde se encuentran los dos contextos funerarios.

Capa «E»: Capa de arena de color gris, entremezclada con cascajo en mayor proporción que la capa D. En el interior de esta capa se halló un contexto funerario. Tiene un grosor de $0,60 \mathrm{~m}$.

Contexto 9: Se trata de un contexto funerario, el cual se ubica en el ángulo formado por los muros I y II, a 0,20 m del muro sur y a 0,24 m del perfil este. La estructura funeraria es simple, sin arquitectura, de forma irregular y de dimensiones: 0,60 $\mathrm{m}$ de alto, por 0,68 $\mathrm{m}$ de ancho y 0,72 $\mathrm{m}$ de largo. La base de la estructura se halló a 2,53 m de profundidad con respecto a la cota. Este contexto funerario está conformado por dos fardos y un conjunto de vasijas asociadas. El fardo $\mathrm{N}^{\circ} 1$, al parecer de un niño, está envuelto con telas llanas y amarradas con soguillas de fibra vegetal. El fardo 1 se encontró en posición extendido en eje norte-sur. Junto al fardo se encontró dos montones de tallos secos de totora, amarradas con hilos en la parte superior. El fardo $\mathrm{N}^{\circ} 2$ se halló al mismo nivel que el anterior, a 0,10 $\mathrm{m}$ de distancia hacia el suroeste del fardo 1, y a 0,20 m del muro sur. Tiene 0,37 $\mathrm{m}$ de ancho por 0,40 $\mathrm{m}$ de largo. Se trata del fardo de un individuo adulto (se observó la rótula del individuo), envuelto en telas llanas y anudado con fibras vegetales. El fardo se halló en posición fetal y en orientación al Norte. Junto a este individuo y en asociación directa se halló ocho husos de diferentes tamaños, algunos con decoración lineal en color negro, pero en proceso de deterioro.

En asociación indirecta a los individuos se halló seis materiales: El primero se ubica al Sur del fardo 1 y está conformado por una vasija de estilo Pativilca (decoración en botones) con cara gollete. Por debajo del nivel de este, a 0,03 $\mathrm{m}$ al Este del fardo 1, se halló la segunda vasija conformada por un cántaro globular de estilo Chancay. A 0,04 $\mathrm{m}$ de distancia, al Este de la segunda asociación se halló la tercera asociación, conformada por un cuenco en cuyo interior se halló otro cuenco más pequeño con una aplicación escultórica de un maíz en el borde. La cuarta asociación se trataba de un cántaro de cuerpo globular extendido en eje vertical, con la boca rota, ya que el cuenco (asociación 3) se hallaba encima ejerciendo presión sobre este. Junto al fardo 
2, hacia el Este, se halló otro cántaro (asociación 5) ligeramente inclinado hacia el noreste y junto a este se halló un instrumento textil (callhua o espada) de madera y apuntada en los extremos.

Piso 5: Tiene 0,04 $\mathrm{m}$ de naturaleza compacta, conformado por tierra de granos finos con algunas piedrecillas. Sobre este piso se ubican los contextos funerarios. Este piso separa el contexto 9 del contexto 10.

Capa F: Capa de arena de color gris, entremezclada con cascajo en iguales proporciones que la capa E. En el interior de esta capa se halló un contexto funerario. Tiene un grosor de $0,60 \mathrm{~m}$.

Contexto 10: Se trata de otro contexto funerario hallado debajo del piso 5, junto al muro I, extendiéndose hasta el perfil norte de la unidad, por lo que se realizó la ampliación hacia este lado. La estructura funeraria es de características similares a la del contexto 9, sin arquitectura, de forma ovalada, no siendo posible definir sus dimensiones. Sobre el nivel de la estructura se halló un tronco quemado a modo de señal. La base de la estructura funeraria se encuentra a 2,80 $\mathrm{m}$ de profundidad con respecto a la cota. Este contexto funerario se caracteriza por presentar tres individuos enfardelados. El fardo 1, al parecer de un niño, ubicado junto al perfil este y a 0,43 m del muro sur; se encontró envuelto en telas y en posición extendida, orientado hacia el Norte. El fardo 2, también perteneciente a un niño (por sus dimensiones), ubicado junto al muro este y a $0,20 \mathrm{~m}$ del muro sur; se encontró en posición extendida y orientado al Norte, envuelto en telas llanas. Los dos fardos ( 1 y 2 ) se hallaron al mismo nivel. A 0,28 m del perfil norte y a 0,76 m del perfil este se halló el fardo 3, correspondiente a un individuo adulto (se observa el cráneo), envuelto en hojas de pacae, en posición extendida y orientado al Norte. Este fardo tiene 0,57 $\mathrm{m}$ de largo, 0,41 $\mathrm{m}$ de ancho y 0,19 $\mathrm{m}$ de grosor.

Al igual que el contexto 9 presenta numerosos materiales en asociación. La asociación 5, conformado por una figurina antropomorfa tipo «cuchimilco», con decoración negro sobre blanco y vestido con un textil, orientado al Este en posición parado, se encontró junto al perfil este de la unidad. Inmediatamente al Oeste de esta figurina se halló las asociaciones 1 y 4 (encima del fardo 1), el primero conformado por una olla de cuello corto con la superficie cubierta de hollín, mientras que la segunda ubicada debajo de la anterior, se trata de una olla de cuello corto, con hollín y un fragmento de cerámica llana a modo de tapa en la boca. La asociación 3 está conformado por una cantimplora Chancay Negro sobre Blanco, con decoración en líneas horizontales, con una tapa conformada por un fragmento cerámico de naturaleza doméstica. Esta cantimplora se halló por encima de las dos ollas y por encima del fardo 1 . Alrededor del fardo 1 se halló abundantes restos alimenticios como pacae y yuca, deshidratadas y dispuestas a modo de ofrendas. Entre los fardos 1 y 2, se halló la asociación 7 , conformado por un cántaro en miniatura, de manufactura rústica, tapado por un cuenco más pequeño con decoración Negro sobre Blanco (decoración lineal) y deformado en el proceso de cocción. Junto al fardo 2, hacia el lado noroeste se halló la asociación 2 conformado por una olla de cuerpo globular de cuello corto, con la superficie cubierta de hollín, con las asas rotas, tapado por un cuenco hecho en mate. Junto a esta olla se halló la asociación 6, conformado por un cántaro grande con representación en alto relieve de una calabaza, con decoración negro sobre blanco, con la boca tapada por un cuenco pequeño. Al mismo nivel del fardo 3, junto al perfil este se halló la asociación 8 conformado por un cántaro con cara gollete y decoración negro sobre blanco, con una tapa de mate. Junto a este cántaro se hallaron dos cuencos de mate, superpuestos (asociaciones 9 y 10). 
Capa «F»: Corresponde a la capa estéril, formada por arena color beige, entremezclada en igual proporción con cascajos.

\section{UNIDAD 3}

Se encuentra localizada en el sector "A», teniendo como centroide las coordenadas UTM: $8724819 \mathrm{~N}$ y $258842 \mathrm{E}$, a una altitud de $231 \mathrm{msnm}$. Es de 2 x $2 \mathrm{~m}$. Se encuentra ubicada en el interior de un recinto de planta rectangular (de $6 \times 4 \mathrm{~m}$ ), en la esquina suroeste del mismo, junto a sus muros divisorios (MI y MII). El muro I, ubicado en el lado oeste de la unidad (de disposición norte-sur), se caracteriza por estar edificado en tapial edificado mediante la técnica de paños murarios, conformado por tres paños superpuestos, con un basamento simple emplazado sobre una compactación de tierra. La superficie muraria no presenta enlucido. Este muro tiene 2,48 $\mathrm{m}$ de alto y $0,75 \mathrm{~m}$ de grosor. El muro se encuentra deteriorado, presentando problemas superficiales y estructurales, como grafitis modernos, erosión basal, grietas y fisuras. El barro con que se ha elaborado las tapias, está mezclado con piedrecillas pequeñas, fragmentería cerámica, restos vegetales, y malacológico. Por su parte, el muro II, es de características similares al anterior, se ubica en el lado sur de la unidad (de disposición este-oeste), tiene entre 0,50 y 0,52 m de alto y 0,70 $\mathrm{m}$ de grosor. El muro II se encuentra adosado al muro I. La cota se ubicó en la cima del muro XX, a 2,28 m sobre la superficie de la unidad. La secuencia estratigráfica identificada en esta unidad es la siguiente:

Capa S: Es de similares características descritas líneas arriba.

Capa «A»: De color gris claro, naturaleza semicompacta, conformado por tierra entremezclada con componentes naturales como piedrecillas y materiales culturales como fragmentería cerámica, retazos textil, material botánico y algunos restos óseos humanos. Tiene un grosor de 0,10 a 0,18 m. En el interior de esta capa, a 2,48 $\mathrm{m}$ de profundidad con respecto a la cota, se halló fragmentado el borde (boca, cuello y cuerpo superior) de un cántaro cara gollete, tipo «china» Negro sobre Blanco, con algunos elementos aplicados como las orejas y los ojos. Se aprecia solo el rostro del lado derecho.

Capa «B»: Capa de 0,20 a 0,25 m de grosor, conformada por tierra de color beige, entremezclada con piedrecillas y abundante material cultural fragmentado. En el interior de esta capa se halló dos cráneos fragmentados y disturbados por acción de huaqueo, a 2,57 $m$ de profundidad con respecto a la cota. El primer cráneo corresponde a un infante de sexo XXX. El cráneo presenta parte del cabello color castaño. El segundo cráneo, ubicado
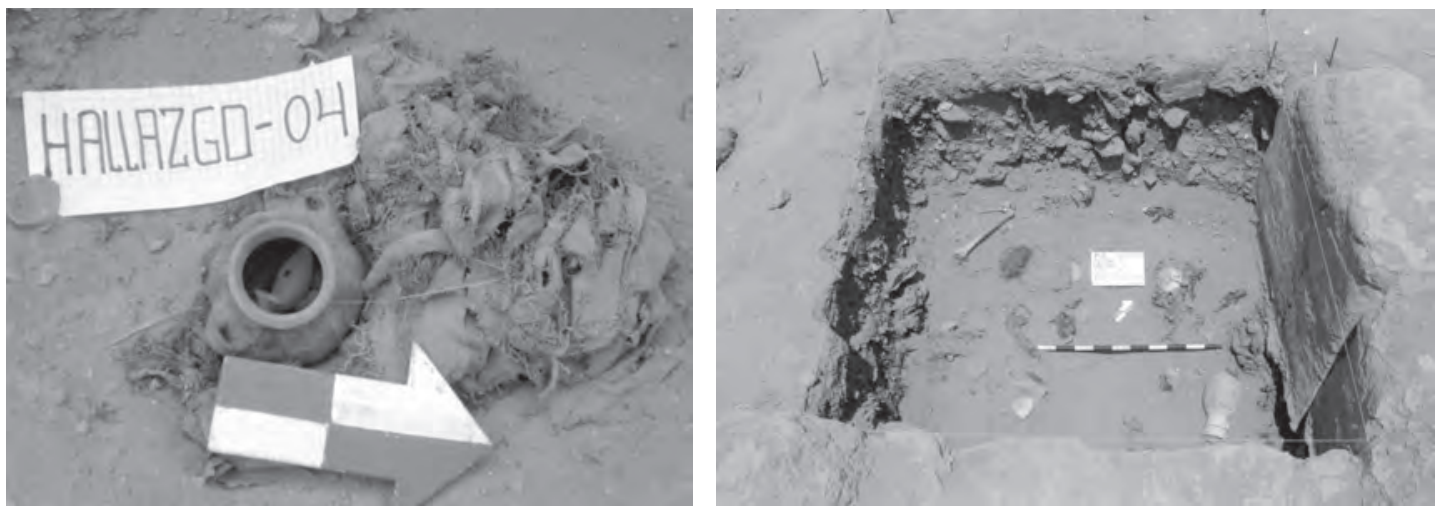

Figura 14 (Izquierda): Vista del contexto 11 formado por una ollita con una conopa de camélido en su interior, unidad 3. Figura 15 (derecha): Vista de la parte superior del contexto 13, nótese la vasija tipo "china» en la esquina inferior derecha, unidad 4. 
junto al primero, a 0,55 $\mathrm{m}$ al Este, corresponde a un individuo adulto de sexo femenino. A 2,63 m de profundidad se halló los restos del Piso 1, muy destruido por la capa B, la cual se intruye la capa que existía debajo.

Capa «C»: Capa de 0,41 $\mathrm{m}$ de grosor, conformada por arena de color beige con tendencia al gris, entremezclada con piedrecillas y abundante material cultural fragmentado, de consistencia suelta. A 3,03 m de profundidad se halló el piso 2, destruido e intruido por la capa $\mathrm{C}$, solo se observa algunos restos de naturaleza semicompacta y 0,03 $\mathrm{m}$ de grosor. En el interior de esta capa se encontró el contexto 11.

Contexto 11: Se encontró a 3,16 m de profundidad con respecto a la cota. Está conformado por una olla de cuello corto, sin decoración de pasta color gris, de $8,5 \mathrm{~cm}$ de alto, boca de $6 \mathrm{~cm}$ de diámetro, forma globular, base convexa y redondeada. En su interior se halló una conopa, conformada por una figurina de camélido de 5,7 cm de largo por $3 \mathrm{~cm}$ de alto. Este contexto se halló junto al muro I.

Capa «D»: Capa de arena fina color beige, de naturaleza semicompacta, entremezclada con gravilla en regular proporción, con escasos materiales culturales (tres fragmentos cerámicos) ubicados en la parte superior, de naturaleza intrusivos. Corresponde a la capa estéril.

\section{UNIDAD 4}

Se encuentra localizada en el sector «A», teniendo como centroide las coordenadas UTM: $8724805 \mathrm{~N}$ y $258832 \mathrm{E}$, a una altitud de $229 \mathrm{msnm}$. Es de 2 x $2 \mathrm{~m}$. Se realizaron dos ampliaciones, de $1 \mathrm{~m}$ al Norte y $1 \mathrm{~m}$ al Oeste. Se encuentra ubicada en el interior de un recinto de planta rectangular (de $6 \times 4 \mathrm{~m}$ ), en la esquina noroeste del mismo, junto a sus muros divisorios (MI y MII). El muro I, ubicado en el lado este de la unidad (de disposición nortesur), se caracteriza por estar edificado en tapial edificado mediante la técnica de paños murarios, con pintura blanca sobre la superficie de $0,3 \mathrm{~cm}$ de grosor, con un basamento simple emplazado sobre una compactación de tierra. Este muro tiene 2,58 $\mathrm{m}$ de alto y $0,70 \mathrm{~m}$ de grosor. El muro se encuentra deteriorado. El barro con que se ha elaborado las tapias, está mezclado con piedrecillas pequeñas, fragmentería cerámica, restos vegetales, y malacológico. Por su parte, el muro II, es de características similares al anterior, se ubica en el lado sur de la unidad (de disposición este-oeste), tiene 2,50 m de alto y 0,70 m de grosor. El muro II se encuentra adosado al muro I. La cota se ubicó en la parte superior de este muro II, a 0,80 $\mathrm{m}$ de la superficie. La secuencia estratigráfica identificada en esta unidad es la siguiente:
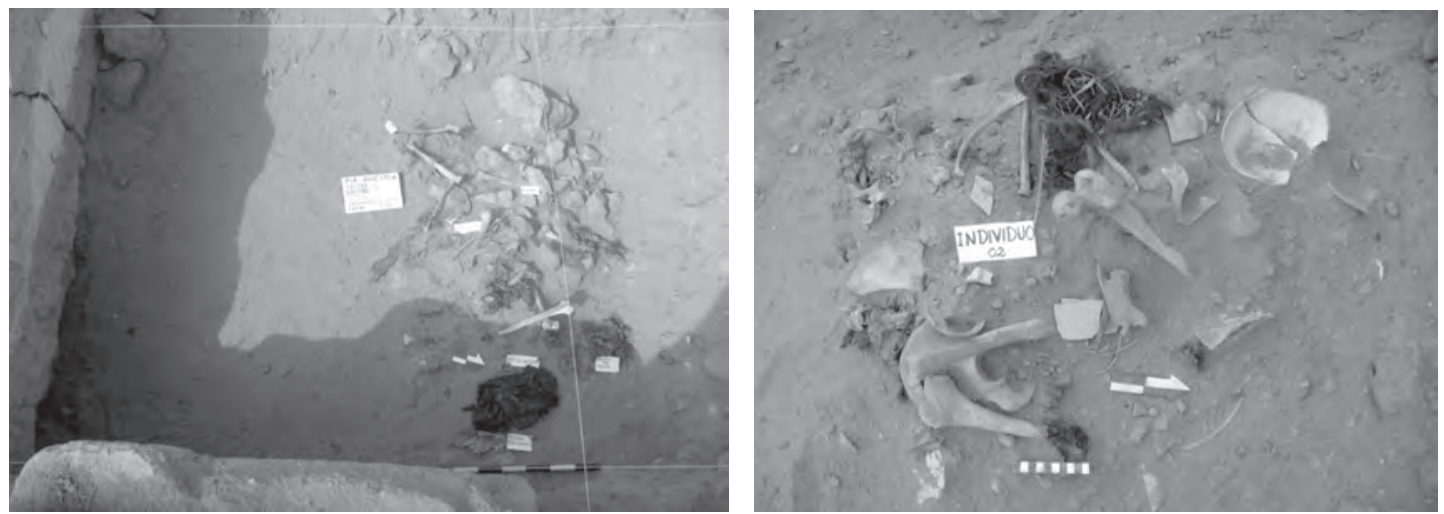

Figura 16 (Izquierda): Individuo 1, Contexto 13, Unidad 4. Figura 17 (derecha): Individuo 2, Contexto 13, Unidad 4. 
Capa S: es de similares características descritas líneas arriba.

Capa «A»: Capa de tierra color beige, de 1,04 m de grosor y naturaleza semicompacta. Esta capa contiene abundantes restos culturales fragmentados. Se halló además restos de tapiales caídos. En el interior de esta capa se halló los contextos 12 y 13.

Contexto 12: Se halló a una profundidad de 1,32 m desde la cota, en el ángulo noroeste de la unidad. Está conformado por un tejido llano de color beige, cabello humano, pelo de camélido, dos fragmentos de cerámica y una cinta con diseños lineales, dispuestos en un espacio de 0,38 x 0,46 $\mathrm{m}$ y de contexto disturbado.

Contexto 13: Se halló a una profundidad de 1,80 m desde la cota. El contexto disturbado, está conformado por una vasija cara gollete escultórica tipo «china»encontrada cerca al ángulo sureste de la unidad, asociado a un conjunto de textiles de diferentes tamaños y colores, mezclados con una gran acumulación de material óseo humano pertenecientes a dos individuos, lo que se extiende hacia los perfiles oeste y norte, por lo que se vio conveniente realizar dos ampliaciones hacia estos lados para una mejor definición del contexto. Los textiles servían de base a los restos óseos. Debajo del hallazgo se encontró un delgado lente de gramíneas mezcladas con algunas hojas de pacae. Los restos óseos del individuo 1, se hallaron en la parte oeste de la unidad y estaba conformado por los dos fémures, tibias, algunas costillas y huesos cortos, colocados sobre un tejido decorado con bandas de diferentes colores.La parte central del tejido presentaba signos de un proceso de desintegración, pues al haber estado colocado inmediatamente sobre el individuo ha degenerado en procesos de destrucción. En uno de los extremos del textil presenta acumulación de hojas de pacae en forma compactada, debido a que debajo del textil se encontraban hojas de pacae colocados a modo de colchón, soportado todo por cañas. Se halló en asociación al individuo, un plato de engobe crema y una cinta hecha con hilo blanco de algodón. Por su parte, los restos del Individuo 2 fueron localizados en el lado norte de la unidad, en un nivel superior con relación al individuo 1. Entre los huesos hallados figuran los dos fémures, una pelvis, algunas vértebras, el sacro, maxilar inferior, fragmento del hueso frontal, un radio y costillas; todo asociado a un pequeño cúmulo de material textil y cabello humano. Una parte delos huesos se hallaron en la ampliación norte.

En la ampliación oeste se encontraron un conjunto de materiales culturales, asociados a los dos individuos que conforman el contexto 13. Estos materiales los hemos denominado como elementos. El Elemento 1 está conformado por algodón trenzado con pequeños nudos de color blanco y marrón. El elemento 2 está conformado por pelo de camélido de color marrón, el cual se encuentra envolviendo hilos y fragmentos textiles. Debajo de estos se halló un hueso frontal humano. El elemento 3 está conformado por un fragmento textil de color beige muy deteriorado. El elemento 4 está conformado por un tejido con decoraciónen bandas de color marrón y blanco, delineadaspor líneas de color azul. El elemento 5 es un fragmento textil de forma alargada con bandas anchas de color marrón y beige y otras bandas medianas de color beige y marrón, delineadas por delgadas líneas de color verde. El elemento 6 está formado por un fragmento de textil envuelto con los bordes dañados y decoración en bandas de color marrón y beige. El elemento 7 está formado por una pequeña red de color beige, tejido con doble hilo en la técnica de anudado, casi integro. Por su parte en la ampliación norte se hallaron otros elementos. El elemento 8 está conformado por un plato localizado en el lado este de la ampliación, debajo del textil asociado al primer individuo. El elemento 9 , ubicado en el lado oeste de la ampliación norte,está conformado por dos cintas anchas de múltiples colores, unidos por un hilo blanco de algodón. El elemento 10 está conformado por una acumulación de 
hojas de pacae, junto al elemento anterior. Por su parte, el elemento 11 está conformado por dos tejidos grandes de color beige con decoración en bandas marrones. Hacia el lado norte del elemento 1, a 0,60 m al Norte se halló restos de piel y óseos de camélido.

Capa «B»: Capa de arena suelta de color gris, de textura suelta y 0,50 m de grosor. Contiene regular cantidad de material cultural entremezclado.

Capa «C»: Capa de arena fina de color beige, de 0,32 $\mathrm{m}$ de grosor, sin material cultural entremezclado. En esta capa se encontró los Contextos 14, 15 y 16.

Contexto 14: Se localiza en la parte central de la unidad, a 2,42 $\mathrm{m}$ de profundidad con respecto al datum, conformado por un tejido decorado con bandas de diferentes colores, el cual envuelve los restos de un animal (cánido), colocado sobre un bloque de tapial caído.

Contexto 15: Se ubica en el lado oeste de la unidad. Está conformado por una vasija doméstica de color negro, con presencia de hollín en el cuerpo y la base. La vasija estaba inclinada y la boca orientada en dirección este. Debajo de la vasija se halló restos textiles y algunos manojos de algodón. Este contexto se halló a 0,25 $\mathrm{m}$ de profundidad con respecto al contexto 14 .

Contexto 16: Se ubica hacia el lado sur, conformado por un plato con engobe parcial en color crema, asociado a cuatro fragmentos Chancay. Se ubica a 2,69 $\mathrm{m}$ de profundidad con respecto al datum.

Capa «D»: Capa estéril de arena color gris, entremezclada con abundantes piedrecillas muy compacta. No presenta material cultural alguno. En la superficie de esta capa se encuentra la base del muro I.

\section{UNIDAD 5}

Se encuentra localizada en el sector «A», teniendo como centroide las coordenadas UTM: $8724760 \mathrm{~N}$ y $258847 \mathrm{E}$, a una altitud de $230 \mathrm{msnm}$. Es de dos por dos metros, con ampliación de 1,50 $\mathrm{m}$ al Este. Se encuentra ubicada en el interior de un recinto de planta rectangular, en la esquina nor-oeste del mismo, junto a sus muros divisorios (MI, MII, MIII y MIV). El muro I, ubicado en el lado oeste de la unidad (de disposición norte-sur), se caracteriza por estar edificado en tapial mediante la técnica de paños murarios, con un basamento simple emplazado sobre una compactación de tierra. Este muro tiene 3,28 $\mathrm{m}$ de alto y $0,47 \mathrm{~m}$ de grosor. El muro se encuentra deteriorado, presentando numerosas grietas. El barro con que se ha elaborado las tapias, está mezclado con piedrecillas pequeñas, fragmentería cerámica, restos vegetales (paja), y malacológico. Por su parte, el muro II, es de características similares al anterior, se ubica en el lado sur de la unidad (de disposición este-oeste), tiene 2,98 $\mathrm{m}$ de alto y 0,30 $\mathrm{m}$ de grosor. El muro II se encuentra adosado al muro I y al muro IV. La cota se ubicó en la parte superior de este muro II, a $0,36 \mathrm{~m}$ de la superficie. Los muros III y IV no eran visibles en la superficie, se fueron definiendo durante la excavación. El muro III se halló a 0,94 m de profundidad con respecto a la cota en el lado norte de la unidad, es de disposición este-oeste. Se adosa al muro IV y tiene $0,30 \mathrm{~m}$ de ancho y 0,60 $\mathrm{m}$ de alto. Presenta decoración muraría pictórica de color blanco. Por su parte, a 0,77 m por debajo de la cota se halló el muro IV, ubicado en el lado este de disposición norte-sur, de 0,46 $\mathrm{m}$ de ancho y una altura de 1,10 $\mathrm{m}$, que adosado a los otros muros, conforma una estructura funeraria que sella los contextos funerarios internos. La secuencia estratigráfica identificada en esta unidad es la siguiente:

Capa S: Es de similares características descritas líneas arriba. 
Capa «A»: Capa de tierra color beige, de 0,50 m de grosor y naturaleza semicompacta. Esta capa contiene abundantes restos culturales fragmentados. Se halló además restos de tapiales caídos. En el interior de esta capa, a 0,62 m de profundidad desde la cota, junto al perfil norte de la unidad, se halló una conopa con representación de un camélido, de 0,12 $\mathrm{m}$ de largo, 0,07 $\mathrm{m}$ de ancho y 0,06 $\mathrm{m}$ de alto, con engobe crema y un agujero en la espalda. Posteriormente, a $0,75 \mathrm{~m}$ debajo de la cota, en medio del relleno y junto al perfil norte de la unidad se halló una chuspa (bolso) con decoración doble cara e interlocking, en colores crema y marrón, con diseños de aves; en su interior contenía algodón. Así mismo, al mismo nivel en la esquina formada por los muros I y II se halló un atado de tela conteniendo en su interior un huso para hilar rodeado de piel y pelo de camélido que envuelven cuentas de material malacológico. En la ampliación este, a 0,77 m de profundidad con respecto a la cota, se identificó la cabecera del muro IV que conforma el muro de una cámara funeraria de los contextos funerarios localizados más abajo (Contexto 17, 18) que fueron disturbados.

Capa «B»: Capa de tierra color beige, entremezclada con piedras pequeñas y abundante material cultural fragmentado.

Tiene un grosor de 0,25 $\mathrm{m}$ y es de naturaleza semicompacta. En la parte media del recinto, lado sur de la unidad (a 0,50 m del perfil sur) se halló una piedra, la cual se extiende hasta el interior de la capa C, por encima del piso 1. En la ampliación este se definió mejor las características del muro IV, de 0,42 m de ancho, de 0,90 m de alto. En esta ampliación se halló dos contextos disturbados.
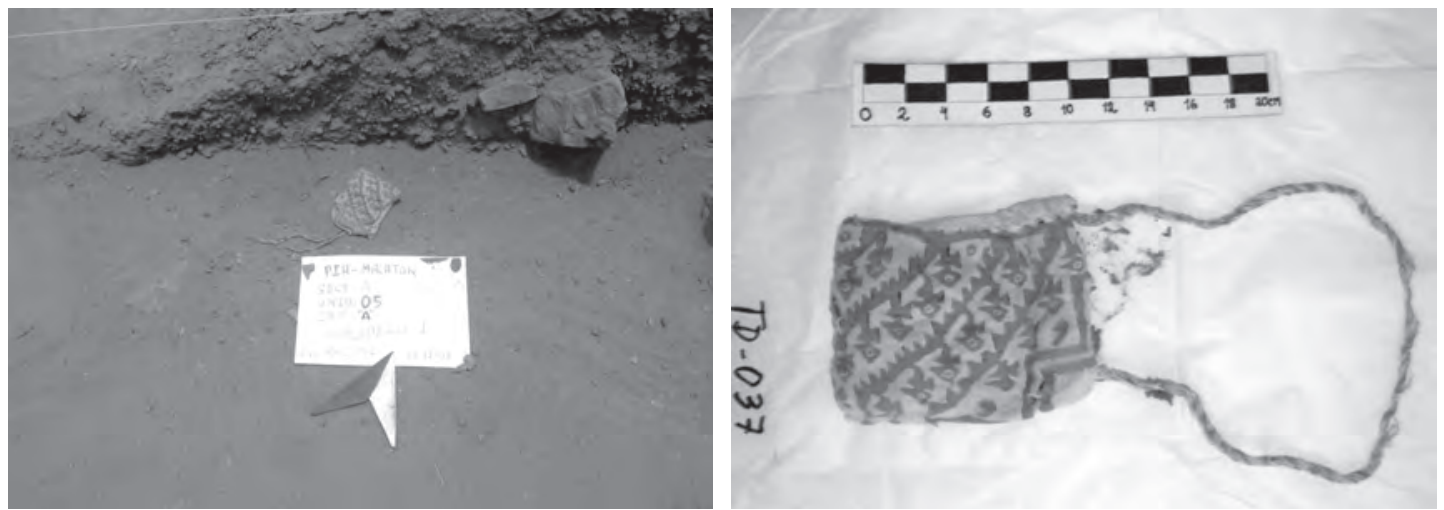

Figura 18 (Izquierda): Contexto en que se halló la chuspa en el interior de la Capa «A», Unidad 5. Figura 19 (derecha): Detalle de la chuspa.

Contexto 17: Se trata de un contexto funerario disturbado por acción del huaqueo, conformado por un individuo de entre 8 y 10 años de edad, enfardelado, de sexo indefinido, en muy mal estado de conservación, dispuesto en posición extendida, en eje este-oeste, con cabello y cuero cabelludo y restos de piel pegada hacia los huesos. Este individuo se halló a $0.99 \mathrm{~m}$ de profundidad con respecto a la cota. Este contexto funerario se halló hacia la esquina noreste de la ampliación este.

Contexto 18: Se trata de otro contexto funerario disturbado, ubicado a 1,02 m de profundidad con respecto a la cota. El individuo es un infante enfardelado, ubicado debajo del muro II. El fardo, ubicado en posición extendida en el eje este-oeste, tiene 0,38 $\mathrm{m}$ de largo, por 0,60 m de ancho y 0,38 m de grosor, y está envuelto por textiles llanos de color beige. Junto al fardo se halló dos vasijas: asociación 1: Olla de cuello corto con hollín en la superficie y mazorcas de maíz en su interior, ubicado hacia el Este del individuo, de 17 $\mathrm{cm}$ de alto y la boca de $9 \mathrm{~cm}$ de diámetro. A $15 \mathrm{~cm}$ al Este del fardo se halló la asociación 

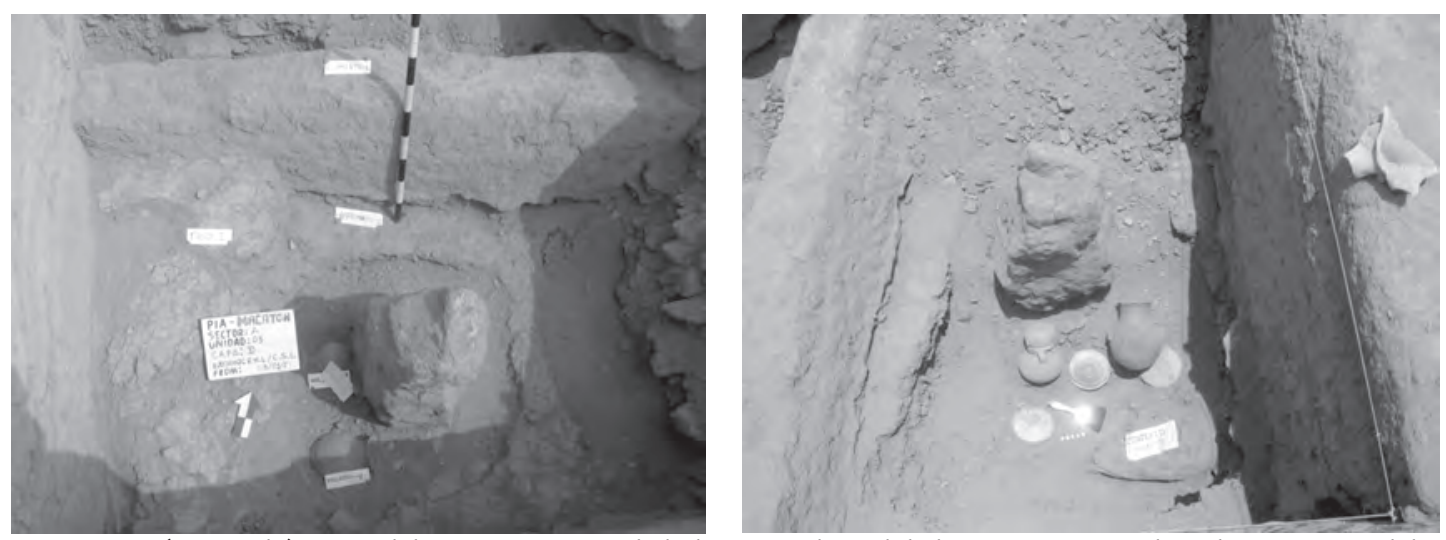

Figura 20 (Izquierda): Vista dela parte superior de la huanca, al nivel de los pisos 1 y 2 , y al fondo una vasija del contexto 18, unidad 5. Figura 21 (derecha): Vista del contexto 18 en asociación a la huanca.

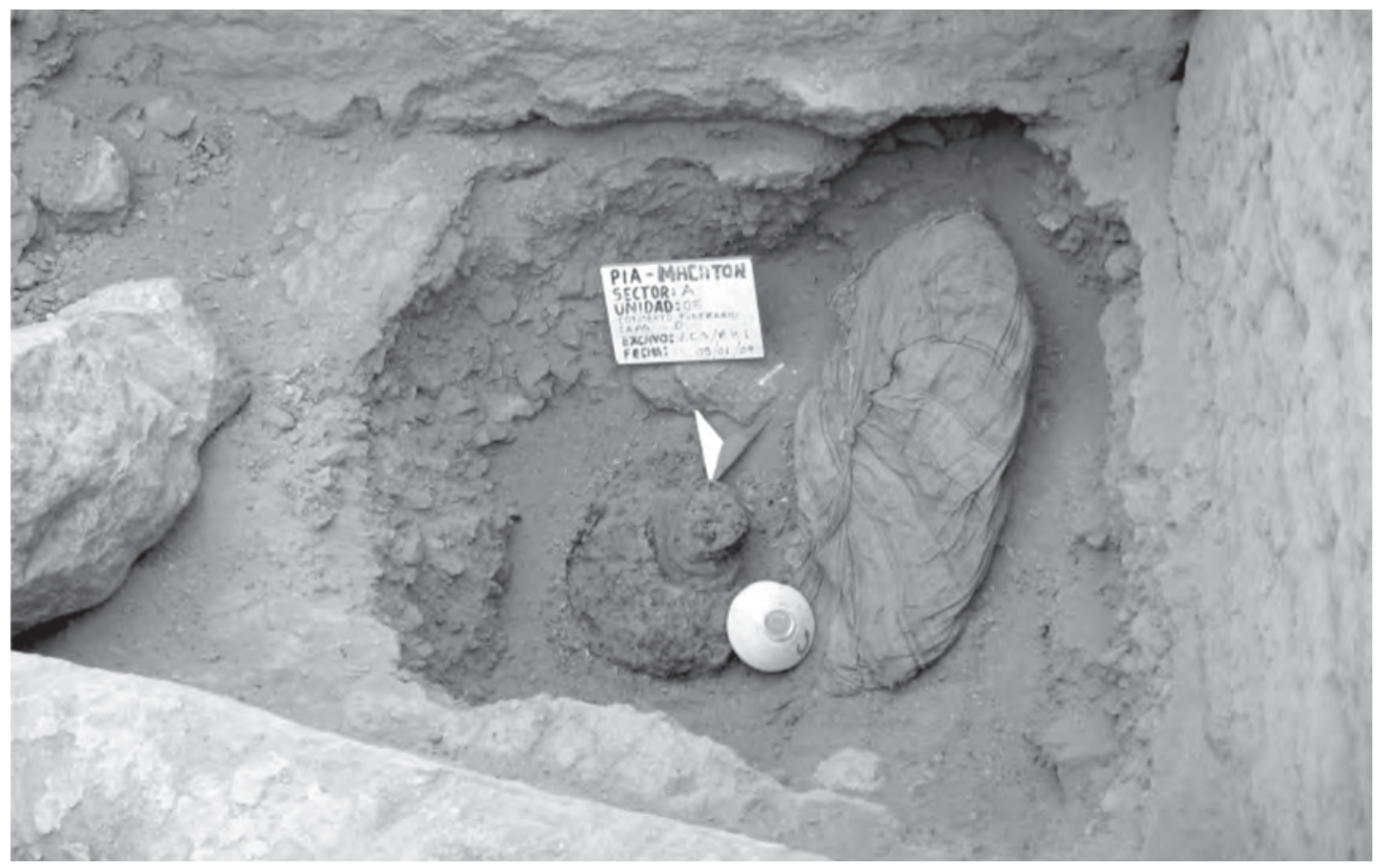

Figura 22: Contexto 19 (fardo extendido envuelto en tejidos listados), asociado a un plato y superpuesto al fardo 2 del contexto 20 (debajo), unidad 5.

2, una olla mediana de cuello corto, cuerpo globular y cubierta de hollín, de $10 \mathrm{~cm}$ de alto y boca de $10 \mathrm{~cm}$. de diámetro.

Capa «C»: Capa de arena suelta color beige, entremezclado con piedras pequeñas y abundante material cultural fragmentado. Tiene un grosor de 0,13 m. En esta capa se definió mejor la piedra ubicada en el lado sur de la unidad, de forma alargada, disposición vertical a modo de huanca, de 0,47 $\mathrm{m}$ de alto, 0,30 $\mathrm{m}$ de diámetro en la parte superior y 0,40 m en la base, la cual se introduce hasta la superficie de la capa «D» y habría sido la marca de la estructura funeraria que encontramos por debajo del piso 2. 
Piso 1: Se ubica a 1,30 m por debajo del nivel de la cota. Es de naturaleza semi compacta, formada por barro con inclusiones de piedrecillas y poca densidad de material cultural (fragmentería cerámica y restos malacológicos). Tiene un grosor de 0,06 m. Presenta un revoque al piso 3. Este piso se encuentra muy deteriorado, pues la huanca se introduce en este, elaborándose un revoque del piso a la huanca. El piso cubre toda la parte interna del recinto.

Piso 2: Inmediatamente debajo del piso 1 hallamos otro piso, también muy deteriorado, con la superficie ubicada a 1,36 m de profundidad con respecto a la cota, de 0,05 $\mathrm{m}$ de grosor y de composición similar al piso 1 . De igual manera, la huanca se introduce en este piso, presentando un revoque del piso a la huanca. La huanca se va a introducir hasta la superficie de la capa D.

Capa «D»: Capa de arena color beige, de un grosor de 1,92 m, de naturaleza semicompacta, conteniendo en su interior con regular densidad de gravilla y regular proporción de material cultural. En el interior de esta capa se encontraron tres contextos funerarios.

Contexto 19: Se trata de un contexto funerario hallado desde los 0,10 $\mathrm{m}$ al interior de la capa D. La estructura funeraria es simple, sin arquitectura, de forma elípticay de dimensiones: 0,51 $\mathrm{m}$ de alto, por 1,10 $\mathrm{m}$ de ancho (eje norte-sur) y 1,20 $\mathrm{m}$ de largo (eje este-oeste). La base de la estructura se halló a 1,64 m de profundidad con respecto a la cota. Este contexto funerario está conformado por un fardo y un conjunto de vasijas asociadas. El fardo, se encuentra extendido en posición horizontal, dispuesto en el eje sur (cabeza) - norte (pies). Se trata de un fardo de $1 \mathrm{~m}$ de largo por 0,50 $\mathrm{m}$ de ancho y 0,45 $\mathrm{m}$ de grosor, con una falsa cabeza de 0,13 m. de largo por 0,20 $\mathrm{m}$ de ancho, y 0,14 $\mathrm{m}$ de grosor, al lado sur. El individuo se encuentra envuelto en textiles de color beige oscuro, con decoración listaba en colores marrón oscuro. Las telas habrían sido cosidas para obtener mayores dimensiones. En la parte media del cuerpo las telas forman un muro doble con el fin de darle mayor estabilidad al envoltorio. El fardo se halló a 1,64 m de profundidad con respecto a la cota.

En asociación indirecta al individuo se halló los siguientes materiales: Asociación 1, conformado por dos platos superpuestos, la primera ubicada debajo cumple propiamente la función de plato, mientras que la segunda cumple la función de tapa, ya que está boca abajo. Ambos platos presentan engobe crema. Los dos platos son de similares características, poca altura $(4,4 \mathrm{~cm})$, y 0,16 $\mathrm{m}$ de diámetro en la boca. Se ubican a 0,20 $\mathrm{m}$ al Norte de los pies del individuo y a 0,20 m por encima del nivel de este. La asociación 2, se ubica inmediatamente a 0,13 $\mathrm{m}$ al Este del anterior, y está conformado por cántaro de cuerpo globular y sobre este un cuenco invertido a modo de tapa. El cántaro tiene 0,14 $\mathrm{m}$ de alto, de color beige claro, asas verticales cintadas con una aplicaciónescultórica de un felino en una de las asas, mientras que del borde sales tres aplicaciones que se desplazan a modo de puente hasta la parte superior del cuerpo. Por su parte el cuenco tiene cuerpo globular, con una boca de $11,5 \mathrm{~cm}$ de diámetro, 7,5 cm de altura. La asociación 3 está conformado por dos platos superpuestos, ubicados a $0,06 \mathrm{~m}$ al sureste del anterior. Los dos platos tienen engobe crema y son de similares características. La asociación 4 está igualmente conformada por dos platos superpuestos, el superior investido a modo de tapa. Se ubica inmediatamente al sur de la asociación 3. La asociación 5 se ubica inmediatamente al sureste del anterior, a $0,03 \mathrm{~m}$, conformado por una olla con cuello, con boca de 0,19 m de diámetro, altura de 0,26 $\mathrm{m}$, de uso doméstico, con la superficie cubierta por hollín, asas cintadas horizontales, cuerpo globular y base redondeada, conteniendo en su interior corontas y granos de maíz. La asociación 6 está conformada por dos platos superpuestos, ubicados parcialmente debajo del cántaro. De igual manera el plato superior se encuentra invertido y tapando al otro. 
Contexto 20: Se trata de un contexto funerario conformado por dos fardos y un conjunto de vasijas asociadas. Los dos fardos se hallaron al mismo nivel y en el interior de una estructura simple, sin arquitectura, de forma irregular, en «8» de 2,10 m de largo por 1,20 $\mathrm{m}$ de ancho y 0,90 $\mathrm{m}$ de altura. El fardo 1 se ubica hacia el lado noreste de la unidad. Se trata de un infante de sexo masculino, enfardelado en textiles llanos de color beige oscuro muy deteriorados, con un relleno interno de hojas de pacae. El fardo tiene 0,42 $\mathrm{m}$ de largo, 0,20 $\mathrm{m}$ de ancho y 0,30 $\mathrm{m}$ de grosor. El fardo se encuentra en posición extendida en el eje este (cabeza) - oeste (pies). La superficie superior del fardo se halló a 1,96 m de profundidad con respecto a la cota, junto al muro III. En asociación al fardo 1 se hallaron 7 vasijas. La asociación 1 está conformado por un cántaro con cara gollete en alto relieve, tipo «china», ubicada por encima del nivel de los dos fardos, hacia el perfil sur de la matriz de la estructura funeraria, a 0,23 m del muro I, a 1,89 m de profundidad de la cota, de cuerpo extendido en el eje vertical, con la representación de las manos en alto relieve en la parte media del cuerpo, con una boca de $12,6 \mathrm{~cm}$ de diámetro, $36,7 \mathrm{~cm}$ de altura, con la mirada orientada hacia el fardo 1. Inmediatamente encima de la cabeza del fardo 1 se encontró la asociación 2, conformada por una olla Lauri Impreso de cuerpo globular de cuello corto y de labio ligeramente evertido, con boca de 0,08 $\mathrm{m}$ de diámetro, 0,15 $\mathrm{m}$ de alto, asas cintadas de color negro y decoración a base de una hilera horizontal de círculos impresos por debajo del labio. Encima de la olla y de forma invertida se halló un cuenco con decoración Negro sobre Blanco, con diseños de aves marinas, líneas horizontales y verticales, geométricos, entre otros; con aplicaciones de dos cabezas de felinos de tamaño pequeño, uno a cada lado. A 0,25 m al Este del fardo se halló la asociación 3, hallado a 1,76 m de profundidad, conformado por un cántaro de cuerpo globular extendido en eje vertical, con decoración negro sobre blanco en bandas verticales que se extienden desde el cuello hasta la base de la
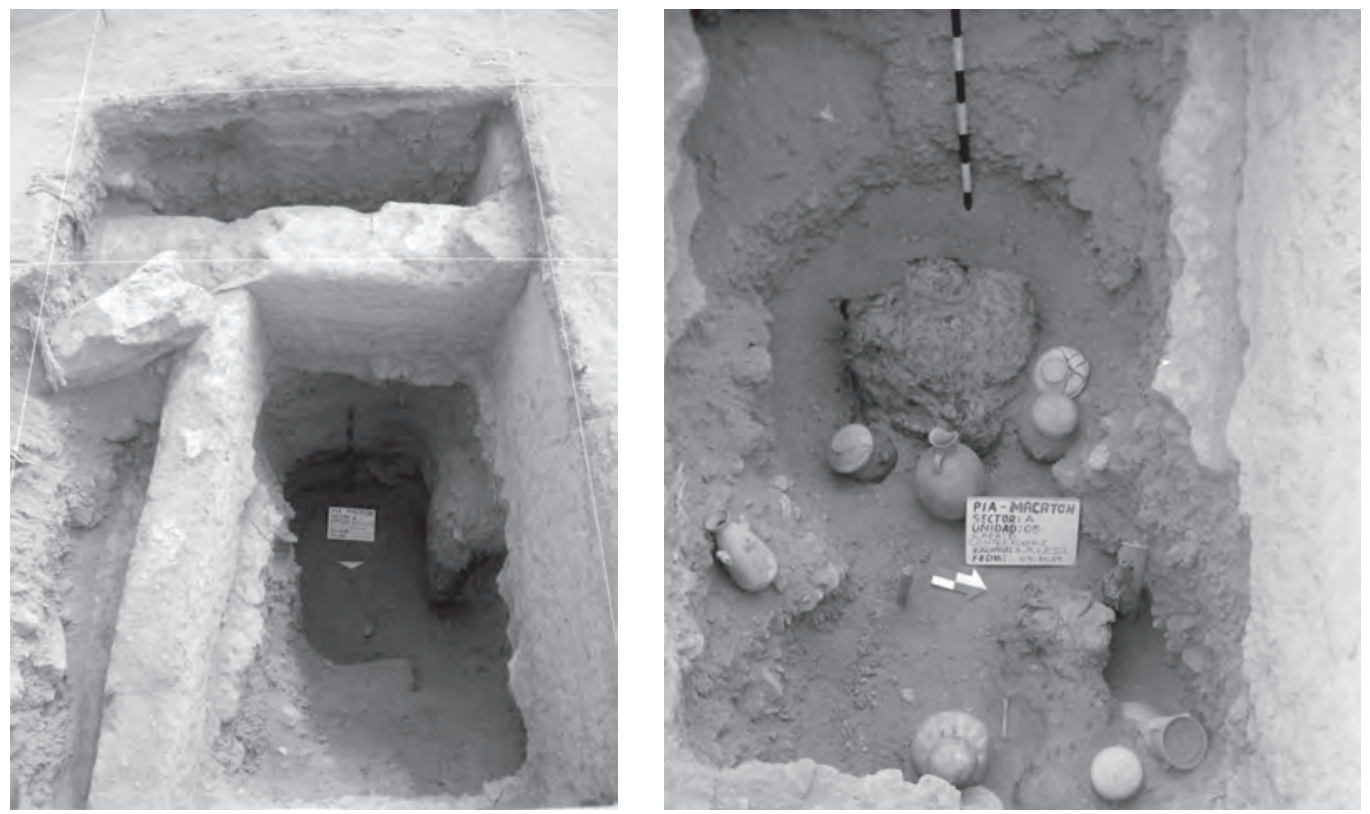

Figura 23 (Izquierda): Cámara funeraria superior, en cuyo interior se hallaron los contextos funerarios de la unidad 5. Figura 24 (derecha): Contexto 20 con el fardo 1 en la parte inferior $y$ el fardo 2 en la parte superior, unidad 5. 
vasija, asas cintadas verticales, con la boca de $8,4 \mathrm{~cm}$ de diámetro y una altura de 27,2 $\mathrm{cm}$. Sobre este cántaro hay un cuenco invertido a modo de tapa, de estilo Tricolor (negro, rojo y blanco), con la boca de $10,3 \mathrm{~cm}$ de diámetro, y 5,6 cm de alto. Junto a estas dos vasijas, inmediatamente hacia el noreste, se halló la asociación 4, ubicado a 0,68 m del muro II y a 0,42 m del muro III, y a 0,02 m del muro IV, a 1,85 m de profundidad. Está conformado por una olla de cuerpo globular fragmentado, con asas cintadas verticales, y cubierta por un plato invertido de engobe crema, de una boca de $13 \mathrm{~cm}$ de diámetro y una equis en la base en alto relieve. Junto a esta olla se encontró la asociación 5, conformado por un cántaro tipo china, ubicado a 1,94 $\mathrm{m}$ de profundidad.

El fardo 2 se ubica hacia el lado oeste de la estructura funeraria. Se trata del fardo de un individuo adulto de sexo aún no identificado de 0,82 $\mathrm{m}$ de alto, entre 0,54 y 0,42 $\mathrm{m}$ de ancho y 0,42 $\mathrm{m}$ de grosor, dispuesto en posición vertical orientado por la mirada de la falsa cabeza hacia el noreste. Posee falsa cabeza de 0,12 $\mathrm{m}$ de alto por 0,16 $\mathrm{m}$ de ancho y $0,12 \mathrm{~m}$ de grosor. Este individuo se ubica a $0,62 \mathrm{~m}$ del perfil oeste (muro I) y a 0,36 m del perfil sur (muro II), al mismo nivel que el fardo 1. Presenta cinco asociaciones, ligeramente separadas entre sí y del fardo, la primera asociación se ubica frente al fardo (0,03 $\mathrm{m}$ de distancia), a 1,92 $\mathrm{m}$ de profundidad con respecto a la cota, está conformado por un cántaro de estilo Chancay con decoración negro sobre blanco conformado por líneas que se extienden en el cuello y cuerpo de la misma, con asas cintadas verticales que unen el cuello con el cuerpo. La segunda asociación está conformada por dos vasijas, una olla y un cuenco invertido a modo de tapa, ubicados a 0,20 $\mathrm{m}$ al noroeste de la anterior; la olla tiene restos de hollín en toda la superficie, tiene $24,4 \mathrm{~cm}$ de altura, con un diámetro de boca de $9,2 \mathrm{~cm}$, asas cintadas pequeñas y horizontales, cuello corto, y sobre esta olla está el cuenco invertido de $11,95 \mathrm{~cm}$ de alto y sin decoración. La asociación 3, ubicada a 0,10 $\mathrm{m}$ al sur de la primera asociación, está conformado por una olla sin decoración de cuerpo globular, de asas horizontales, de 15,5 cm de alto, boca de $8,8 \mathrm{~cm}$ de diámetro, con la superficie cubierta por hollín, y conteniendo en su interior un textil quemado; sobre la olla se encontraron dos platos invertidos y superpuestos, el inferior con decoración lineal negro sobre blanco y el otro con engobe crema y una marca a modo de equis en la base. La cuarta asociación está conformada por dos platos superpuestos de engobe crema en la superficie interna y externa (hallados fragmentados), el superior invertido a modo de tapa, ubicados inmediatamente al Oeste de la segunda asociación. La quinta asociación se halló más alejado del fardo, a 0,72 $\mathrm{m}$ al sureste del mismo, (a igual distancia del fardo 1), conformado por un cántaro de forma ovoide extendido en el eje vertical, de cuello corto, abierto y ligeramente evertido, asas cintadas pequeñas y horizontales, con aplicación de dos figuras zoomorfas hacia las partes laterales del cuerpo, con decoración negro sobre blanco. Esta vasija tiene 21,5 $\mathrm{cm}$ de alto y el diámetro de la boca es de $5,9 \mathrm{~cm}$.

Contexto 21: Se trata de otro contexto funerario ubicado debajo del anterior y al que se le superpone también el contexto 18. La estructura funeraria de forma irregular, estrecho, de fondo ovalado con una extensión hacia el lado oeste, de 0,96 m (eje norte-sur) por $1 \mathrm{~m}$ (eje este-oeste) y 1,10 m de profundidad. No presenta arquitectura funeraria. El individuo se encuentra colocado al interior de un fardo, ubicado en el lado central oriental de la estructura. El fardo se encuentra en posición vertical, de 0,65 $\mathrm{m}$ de ancho, $1,24 \mathrm{~m}$ de alto y $0,28 \mathrm{~m}$ de grosor, y está elaborado con textiles llanos y decorados en colores: negro, marrón y azul. Tiene una falsa cabeza de 0,20 $\mathrm{m}$ de ancho, 0,12 $\mathrm{m}$ de alto y $0,16 \mathrm{~m}$ de grosor. El fardo se encuentra orientado por la mirada hacia el Este. Junto a los hombros del fardo se hallaron carrizos colocados en posición vertical, mientras que a su lado izquierdo se hallaron implementos textiles. La parte superior del fardo 


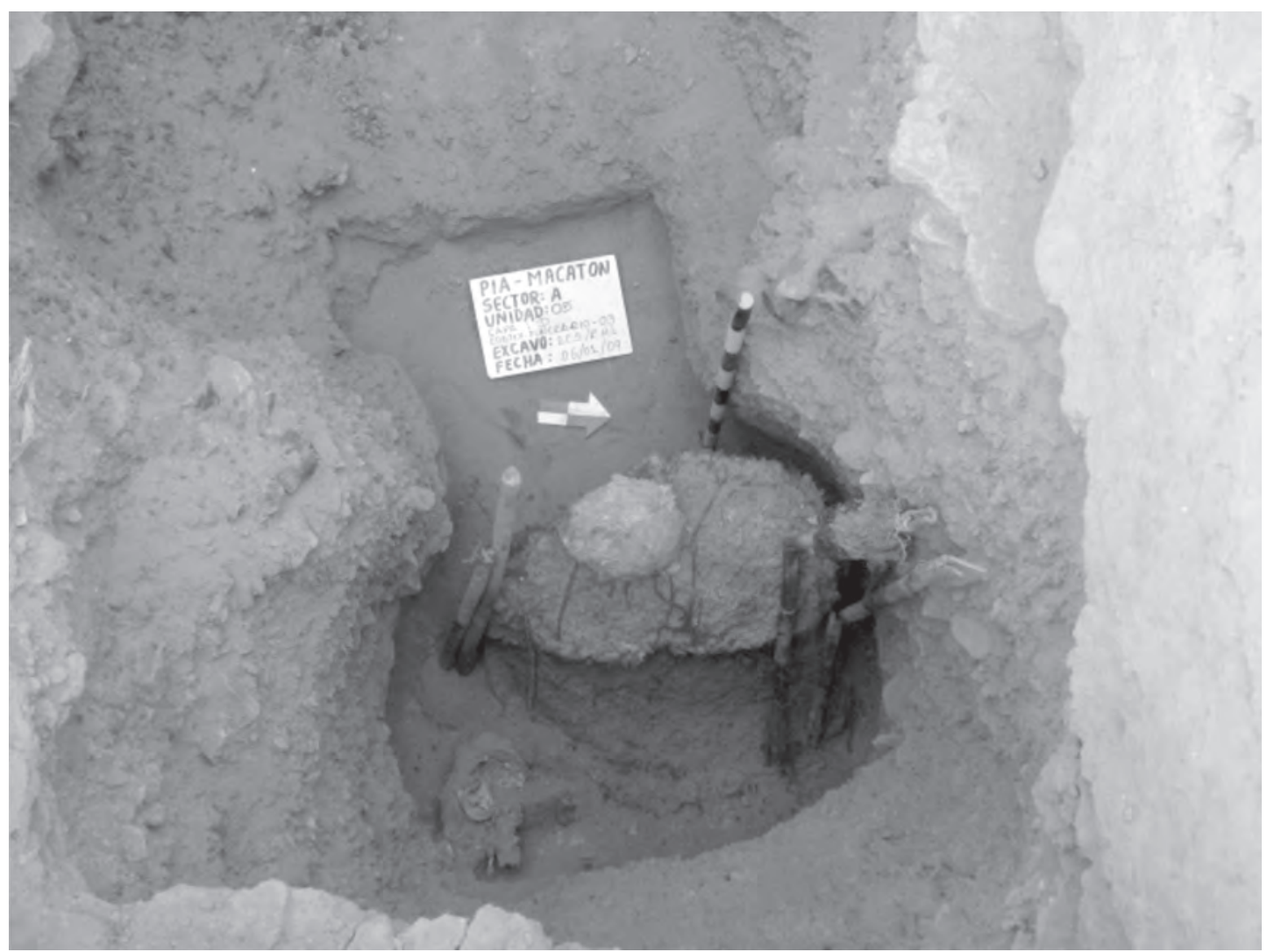

Figura 25: Vista del contexto 21 con su falsa cabeza y sus báculos laterales, unidad 5.

se halló a 2,24 m de profundidad con respecto a la cota. Presenta nueve asociaciones, ubicados en la parte anterior y posterior del fardo. La primera asociación, ubicada a 2,38 m de profundidad de la cota, ubicada inmediatamente al frente del fardo, conformada por dos platos superpuestos, el superior investido a modo de cubierta, ambos con engobe crema interno y externo en la mitad superior de los mismos, de $4,9 \mathrm{~cm}$ de alto y boca de 13,7 cm de diámetro, de base anular. La asociación 2, ubicada junto al anterior, al Norte, está conformado por otros dos platos superpuestos, el superior invertido, de engobe crema parcial en la superficie interna y externa, de $6 \mathrm{~cm}$ de alto y la boca de $13 \mathrm{~cm}$ de diámetro y base anular. La asociación 3, ubicada junto a la anterior también presenta dos platos superpuestos, el superior invertido, de engobe crema total interno y externo, el inferior con un círculo en alto relieve en la base. La asociación 4, ubicado junto al anterior, está formado por un cántaro de engobe crema en el interior del cuello evertido, sin presentar decoración en el resto de la vasija. Presenta asas tubulares trenzadas verticales. Este cántaro tiene $17,8 \mathrm{~cm}$ de alto, boca de $14,8 \mathrm{~cm}$ de diámetro, cuello divergente convexo de $8,8 \mathrm{~cm}$ de alto, base redondeada. Sobre la boca de este cántaro se superpone un cuenco, con decoración negro sobre blanco, con dos aplicaciones zoomorfas (cabezas de felinos) a cada extremo de la vasija. Este cuenco de 8,1 $\mathrm{cm}$ de alto, y boca de 9,7 cm de diámetro, presenta seis diseños de pelícanos alrededor del cuerpo. Junto a esta asociación y al fardo, se ubica la asociación 4, a 2,29 m de profundidad desde la cota, conformado por una olla de cuello corto, cuerpo globular 
y con huellas de hollín, de $16,4 \mathrm{~cm}$ de alto, la boca de $9.1 \mathrm{~cm}$ de diámetro y las asas trenzadas laterales verticales. Sobre esta olla hay un cuenco invertido con decoración negro sobre blanco, de diseños ondulantes, con una altura de $6,1 \mathrm{~cm}$ y boca de $11,1 \mathrm{~cm}$ de diámetro. La asociación 5, se ubica a 0,21 m hacia el Este del fardo y está conformado por un cántaro con decoración negro sobre blanco, de $18 \mathrm{~cm}$ de alto, boca de 7,9 cm de diámetro, asas laterales verticales y trenzadas. Junto a esta se halló la asociación 6, ubicada a 2,23 m de profundidad con respecto a la cota, conformada por un cántaro con decoración negro sobre blanco (lineal, punteada y geométrica), con una aplicación zoomorfa (mono) hacia un lado, de $23 \mathrm{~cm}$ de alto y la boca de $6 \mathrm{~cm}$ de diámetro. A 0,14 $\mathrm{m}$ al Sur del fardo se halló la asociación 7 , conformado por una vasija de cara gollete tipo «china», con decoración negro sobre blanco, de $33 \mathrm{~cm}$ de alto y boca de 13,8 cm de diámetro, base redondeada y ubicada a 2,16 m de profundidad desde la cota. A modo de tapa presenta un plato invertido, de base anular con una equis central en alto relieve. Junto a este se halló la asociación $\mathbf{8}$, conformado por una olla mediana de cuello corto y cuerpo globular, de 10,9 cm de alto, boca de 7,6 cm de diámetro, con la superficie cubierta por hollín, asas cintadas laterales pequeñas y verticales. Se ubica a 2,32 m de profundidad desde la cota. Inmediatamente junto a esta olla y al mismo nivel, a 0,05 m al Sur del fardo, se halló la asociación 9, conformado por dos platos de características similares, de 4,5 cm de alto, y la boca de $16 \mathrm{~cm}$, ambos platos fragmentados. A 0,14 $\mathrm{m}$ al oeste del fardo, a espaldas de este, se halló la asociación 10, conformado por una olla mediana de $18 \mathrm{~cm}$ de alto y la boca de $9 \mathrm{~cm}$, sin decoración. Esta olla presenta a modo de tapa un cuenco invertido de $11 \mathrm{~cm}$ de alto y la boca de $12 \mathrm{~cm}$ de diámetro, también sin decoración. Esta asociación se halló a 2,18 m de profundidad desde la cota.

Capa «E»: Capa estéril de arena fina de color gris, entremezclada con abundantes piedrecillas, muy compacta. No presenta material cultural alguno.

\section{MATERIALES RECUPERADOS EN LA EXCAVACIÓN}

Como se ha descrito en la secuencia estratigráfica y de hallazgos identificados durante las excavaciones, ha sido posible recuperar abundantes materiales culturales, de todo tipo, principalmente textiles, óseos humanos, botánico y cerámica.

\section{CERÁMICA}

Las vasijas identificadas asociadas a los contextos funerarios hallados durante la excavación corresponden a la cultura Chancay. La disposición de las vasijas en la estructura funeraria se da alrededor del individuo, en algunos casos en hasta tres niveles, por lo general las vasijas presentaban en la parte superior de la boca otra vasija invertida a modo de tapa, siendo a veces la vasija reemplazada por un mate. Algunas vasijas presentaban en su interior restos alimenticios a modo de ofrendas.

De manera general se ha realizado una pequeña tipología solo de las vasijas completas que se encontraron acompañando los contextos funerarios. El análisis tipológico completo será motivo de un nuevo artículo.

\section{Estilo Chancay}

El estilo Chancay es el estilo cerámico característico de la cultura Chancay, cuya dispersión abarca todo el territorio Chancay, por el Norte hasta los valles de Fortaleza y Pativilca, por el Sur hasta el valle de Chillón. Sin embargo, se trataría de un estilo originario del valle Chancay-Huaral, que luego se expandió por los valles aledaños. Presenta tres tipos, el Negro sobre Blanco, el Base crema y el Doméstico sin decoración. Las formas de este estilo identificadas en las excavaciones son: 

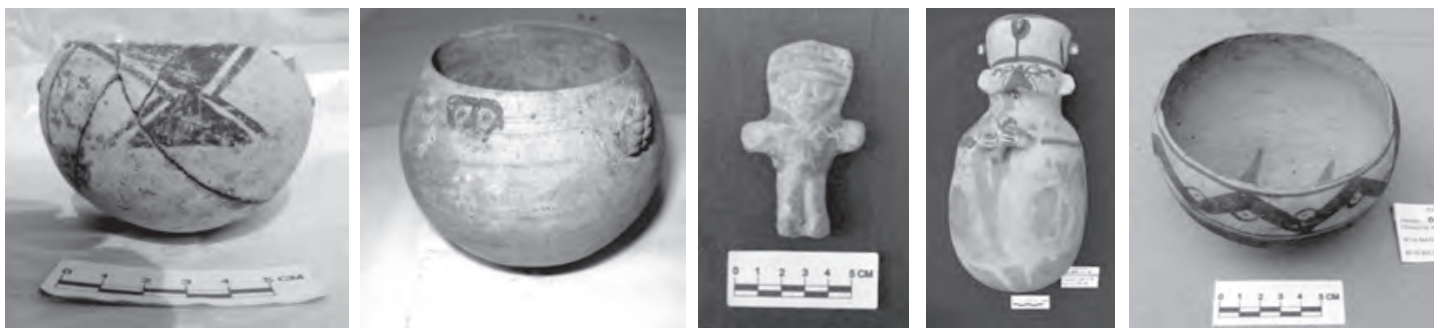

Figura 26 (Izquierda): Cuenco Chancay Negro sobre Blanco. Figura 27 (centro izquierda): Cuenco Chancay Negro sobre Blanco, con maíz. Figura 28 (centro): Figurina tipo "cuchimilco» Chancay Negro sobre Blanco. Figura 29 (centro derecha): Cántaro Chancay Negro sobre Blanco, con cara gollete, tipo «china». Figura 30 (derecha): Cuenco Chancay Negro sobre Blanco.
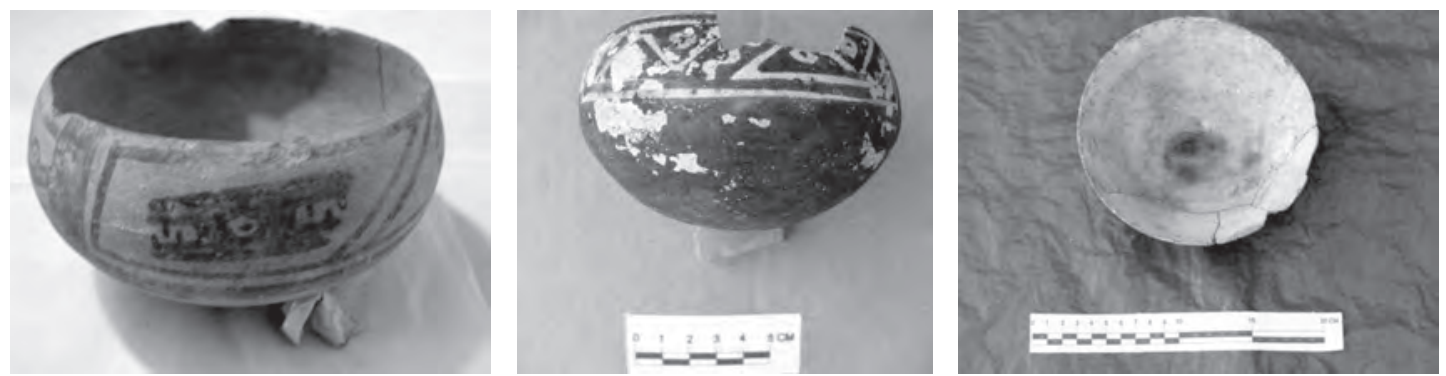

Figura 31 (Izquierda): cuenco Estilo Tricolor, inicios del Intermedio Tardio, con decoración de cabezas de felinos en perfil. Figura 32 (centro): cuenco Chancay negro sobre blanco. Figura 33 (derecha): plato Chancay tipo crema.
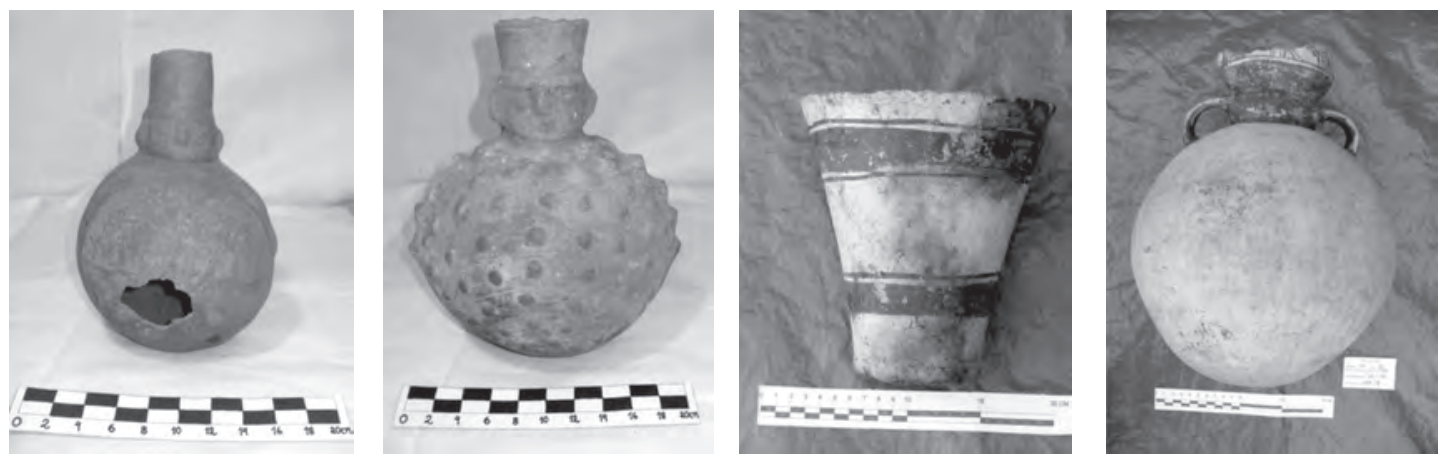

Figura 34 (Izquierda): Botella de estilo Teatino. Figura 35 (centro izquierda): Botella de estilo Pativilca. Figura 36 (centro derecha): Kero Chancay negro sobre blanco. Figura 37 (derecha): Cántaro Chancay negro sobre blanco.

\subsection{Tipo Negro sobre Blanco}

\section{A. Cuencos}

Tipo 1:Vasija de engobe crema, cuerpo semiglobular convexo, de $6 \mathrm{~cm}$ de alto, boca de 5,5 $\mathrm{cm}$, con decoración debajo del labio de círculos estilizados a modo de ojos con líneas de color negro y fondo crema. Presenta debajo del labio, en la parte anterior la aplicación de una mazorca de maíz de $1,5 \mathrm{~cm}$ de alto (CF 3A-B).

Tipo 2: Cuenco mediano de $8 \mathrm{~cm}$ de alto y boca de $7,5 \mathrm{~cm}$ de diámetro, de cuerpo semiglobular, base redondeada. Presenta la aplicación de dos pequeños apéndices en los extremos a modo de agarraderas pero sin orificio. Presenta engobe crema, con decoración geométrica y lineal en la mitad superior del cuerpo en color negro. 
Tipo 3: Cuenco de boca mediana de $9 \mathrm{~cm}$ de diámetro, en total de $6 \mathrm{~cm}$ de alto, de cuerpo semiglobular, con dos aplicaciones debajo del borde a modo de agarraderas, y base plana. La pasta es crema, cocción oxidante y engobe total crema. Presenta en el cuerpo superior dos bandas laterales verticales en color negro que abarca las agarraderas, así como dos aves pequeñas alineadas en eje horizontal, tanto en la parte anterior como posterior.

Tipo 4: Cuenco de $7 \mathrm{~cm}$ de alto, y boca de $16 \mathrm{~cm}$ de diámetro de cuerpo semiglobular extendido en eje horizontal, base redondeada. Presenta decoración en la mitad superior del cuerpo, conformado por bandas verticales y horizontales, y líneas onduladas. La pasta es color crema y la cocción oxidante.

B. Vasos

Tipo 1: Vaso de $14 \mathrm{~cm}$ de alto, boca de $13 \mathrm{~cm}$ de diámetro, cuerpo extendido divergente, recto, base plana. Presenta engobe crema, pero justo debajo del borde presenta una línea vertical de 2,5 cm de largo en color negro.Hay una vasija del mismo tipo de forma, que se diferencia por tener $17,5 \mathrm{~cm}$ de alto y boca de $16 \mathrm{~cm}$ de diámetro, con decoración en bandas y líneas horizontales en color negro que contornean la vasija.

C. Platos

Tipo 1: Plato bajo, de 3,5 cm de alto, boca de $14 \mathrm{~cm}$ de diámetro, borde directo, labio apuntado, cuerpo ligeramente convexo, de base anular. Presenta engobe crema total. En la base presenta una línea ondulada abierta de color negro.

\section{Cántaros}

Tipo 1: Cántaro muy similar al tipo 2 de la forma de cántaros del tipo Crema del estilo Chancay, de iguales dimensiones. Con la diferencia que presenta el cuello superior abierto divergente convexo, con un pequeño apéndice a cada lado, y con decoración también en el cuello superior conformado por una banda horizontal con motivos internos geométricos, lineales y escalonados en color negro y fondo crema. Además todo el cuerpo y cuello inferior posterior está pintado de color negro (marrón oscuro).

Tipo 2: Cántaro tipo «china» de cara gollete. Tiene $38 \mathrm{~cm}$ de alto, boca de $13 \mathrm{~cm}$ de diámetro. El cuello está dividido en dos áreas: el superior es divergente ligeramente convexo, con dos apéndices a cada lado de forma horizontal; y el inferior es también divergente pero con la representación en alto relieve de una cara antropomorfa, con la representación de los ojos, las orejas laterales, la nariz y la boca, con pintura facial en color negro delineando los ojos. El cuerpo es extendido en el eje vertical, con la representación en alto relieve de los dos brazos dispuestos horizontalmente en la parte inferior de la tercera parte superior del cuerpo, las cuales al medio están cogiendo una copita aplicada. La base es redondeada. Los brazos presentan decoración en color negro. La vasija presenta engobe crema incompleta sobre la pasta naranja que se observa en algunas áreas.

\subsection{Tipo Crema}

Son aquellas vasijas que presentan solo engobe crema, sea externo o interno, parcial o total.

\section{A. Platos}

Tipo 1: Plato de 5 a 5,5 $\mathrm{cm}$ de alto, con boca de $15 \mathrm{~cm}$ de diámetro, de cuerpo divergente recto, base anular. La pasta es color crema, de cocción oxidante. Presenta engobe crema total.

Tipo 2: Plato de mediana altura, pasta naranja, cocción oxidante, de $4,5 \mathrm{~cm}$ de alto, boca de $16 \mathrm{~cm}$, borde engrosado externo con un apéndice en el extremo superior externo elaborado mediante una aplicación de arcilla (uno a cada lado), cuerpo recto con algunas ondulaciones, base anular. Presenta tres aplicaciones pequeñas en el cuerpo anterior y otras tres en el cuerpo posterior. 


\section{B. Cántaros}

Tipo 1: Cántaro de 17,5 $\mathrm{cm}$ de alto, boca de $10 \mathrm{~cm}$ de diámetro, cuello corto $(2 \mathrm{~cm}$ de alto) ligeramente cóncavo divergente y ligeramente evertido, asas laterales medianas verticales y cintadas ubicadas en el cuerpo superior, cuerpo globular, achatado en los polos, con base plana. Hay una variante de este.

Tipo 2: Cántaro de $31 \mathrm{~cm}$ de alto, boca de $10 \mathrm{~cm}$ de diámetro, cuello doble, el superior es convexo a modo de embudo y el inferior es más pequeño pero también convexo. La unión cuellocuerpo es marcada. Las asas son cintadas verticales y laterales, unen el cuello inferior con el cuerpo superior. El cuerpo es globular extendido en el eje vertical, presenta la aplicación de una cara de felino en medio del cuerpo superior, parte anterior. La base es ligeramente plana.

\section{Cuencos}

Tipo 1: Cuenco de 7,8 cm de alto, boca de $10 \mathrm{~cm}$ de diámetro, de cuello corto divergente y recto, cuerpo semiglobular, asas pequeñas, horizontales y laterales. La base es redondeada.

\section{Figurinas}

Tipo 1: Se identificó la parte inferior de una figurina pequeña de camélido. Tiene $4 \mathrm{~cm}$ de alto. Se nota la mitad inferior con las extremidades inferiores.

\subsection{Estilo Chancay Doméstico sin decoración}

\section{A. Cántaros}

Tipo 1: Vasija de cuerpo extendido ligeramente alargado en eje vertical, de asas pequeñas cintadas verticales. El cuello es convexo directo a modo de embudo de $4,5 \mathrm{~cm}$ de alto. La vasija presenta engobe naranja, la superficie está deteriorado por acción de hongos. La vasija tiene $20 \mathrm{~cm}$ de alto y la boca un diámetro de $6,5 \mathrm{~cm}$. No presenta pintura. Está muy deteriorado (CF-004).

Tipo 2: Este tipo es similar al Tipo 1 de la forma de cántaros del tipo Crema del estilo Chancay, de la misma altura de 17,5 a $26 \mathrm{~cm}$, boca de 14 a 13,5 cm de diámetro, con la diferencia que presenta las asas horizontales en el cuerpo superior y no presenta engobe.

B. Ollas

Tipo 1: Olla mediana de $25 \mathrm{~cm}$ de alto, boca de $14 \mathrm{~cm}$ de diámetro. El cuello es corto, de 1,3 $\mathrm{cm}$ de alto, divergente ligeramente cóncavo, cuerpo globular, con asas laterales cintadas y horizontales ubicadas en el cuerpo superior y base redondeada. Hay un ejemplar de tamaño más pequeño.

\section{Estilo Tricolor}

El estilo Tricolor corresponde a un estilo de inicios del Intermedio Tardío, caracterizado por presentan el fondo crema y la decoración a base de figuras en color negro y rojo. Las formas de este estilo identificadas en las excavaciones son:

\section{A. Cántaros}

Tipo 1: Cántaro de $25 \mathrm{~cm}$ de alto, boca de $10 \mathrm{~cm}$ de diámetro, cuello doble: el superior es corto y recto y el inferior es divergente recto. Las asas son medianas, cintadas, laterales, unen el cuello inferior con el cuerpo superior. El cuerpo es globular, la base redondeada. La pasta es naranja, de cocción oxidante. La vasija, de engobe crema, presenta una gran banda cuadrangular que encierra todo el cuerpo superior de la parte anterior. La banda está definida por una línea gruesa de color rojo, reforzado por una línea de color negro en el extremo externo, 
la cual al llegar debajo de las asas, asciende hasta pasar por el medio de las mismas y llega al borde. En la parte inferior interna de la banda presenta figuras de pequeños felinos alineados en eje horizontal. En el cuello superior presenta una banda horizontal, en cuyo interior hay figuras geométricas y escalonados de fondo crema, pero delineados en color negro.

\section{B. Cuencos}

Tipo 1: Cuenco de cuerpo semiglobular, de $6 \mathrm{~cm}$ de alto y boca de $11 \mathrm{~cm}$ de diámetro. La pasta es color naranja sobrer la cual se ha aplicado engobe crema. Presenta, en la tercera parte superior dos bandas horizontales alineadas, una en la parte anterior y la otra en la posterior. La banda posterior presenta una figura alargada zigzagueante, delineada por dos líneas negras y fondo rojo, con semicírculos laterales en cada ángulo en que cambia de rumbo, con punto negro interno. La banda anterior por su parte presenta cabezas de felino de perfil y estilizadas de líneas color negro con fondo rojo, el extremo de la cabeza se extiende hacia ambos lados (biapendicular), donde se aprecian los dientes. El ojo se ubica en el medio de la cabeza.

\section{Estilo Teatino}

El estilo Teatino es un estilo del Horizonte Medio 3, definido por Julio C. Tello y Bonavía. Tiene amplia distribución en el valle Chancay y se podría considerar a Teatino como perteneciente a la etapa inicial de la cultura Chancay. Las formas de este estilo identificadas en las excavaciones son:

\section{A. Botellas}

Tipo 1: Botella de $23 \mathrm{~cm}$ de alto, sin asas. La boca tiene $4,5 \mathrm{~cm}$ de diámetro, el cuello es tubular de $8 \mathrm{~cm}$ de alto, convergente recto, con la figura de una cara en la parte anterior de representación antropomorfa en alto relieve, del cual se notan los ojos, la nariz, la boca. El cuerpo es globular con achatamiento en la parte posterior y anterior, presenta en la parte anterior una figura antropomorfa divinizada con tocados sobre la cabeza que se convierten en el extremo en serpientes, y otros en motivos aflechados. En la parte posterior se aprecian los cabellos que descienden en alto relieve desde la nuca de la cabeza. La base es plana.

\section{Estilo Pampa de Animas}

Se trata de un estilo nuevo que hemos definido a partir de las investigaciones en el sitio de Pampa de Animas, donde se ha encontrado en regular proporción, correspondiente al Horizonte Medio 3 y 4 , y de expansión hasta adentrado el Intermedio Tardío. Las formas de este estilo identificadas en las excavaciones de Macatón son:

\section{A. Cántaros}

Tipo 1: Vasija engobe marrón, cocción incompleta, sin asas, cuerpo globular angular en la parte media (que divide el cuerpo superior del inferior), de $17 \mathrm{~cm}$ de alto y boca de $6 \mathrm{~cm}$ diámetro. Presenta decoración diluida blanca sobre el engobe marrón, conformado por círculos grandes irregulares en la parte superior del cuerpo. El cuello es corto, ligeramente cóncavo y el borde ligeramente evertido. La base es plana.

\section{Estilo Pativilca}

El estilo Pativilca es otro estilo de la segunda mitad del Horizonte Medio, cuyo centro de dispersión son los valles de Pativilca y Supe. Sin embargo, su expansión y área de influencia puede llegar hasta el valle de Chancay. Algunas vasijas de estilo Chancay presentan algunos motivos iconográficos de este estilo, los cuales se mantienen en el Intermedio Tardío a pesar del tiempo. Las formas de este estilo identificadas en las excavaciones son: 


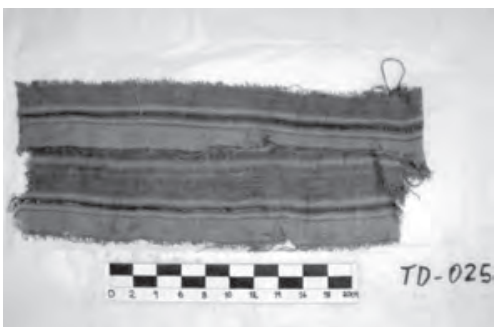

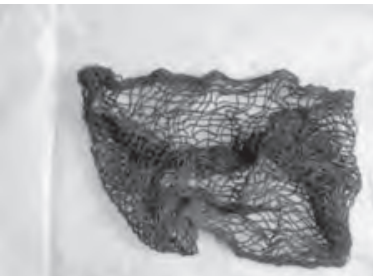

TD.036 A

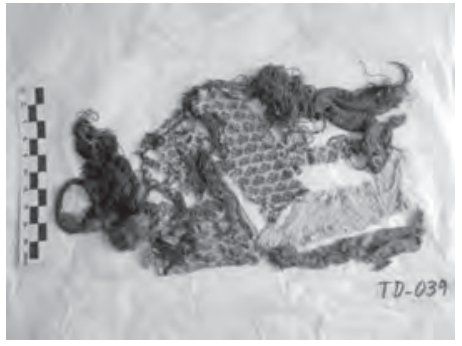

Figura 38 (Izquierda): Tejido Chancay listado. Figura 39 (centro): Malla hecha a base de cabellos humanos para colocar en la cabeza. Figura 40 (derecha): Faja Chancay negro sobre blanco con flecos rojos.
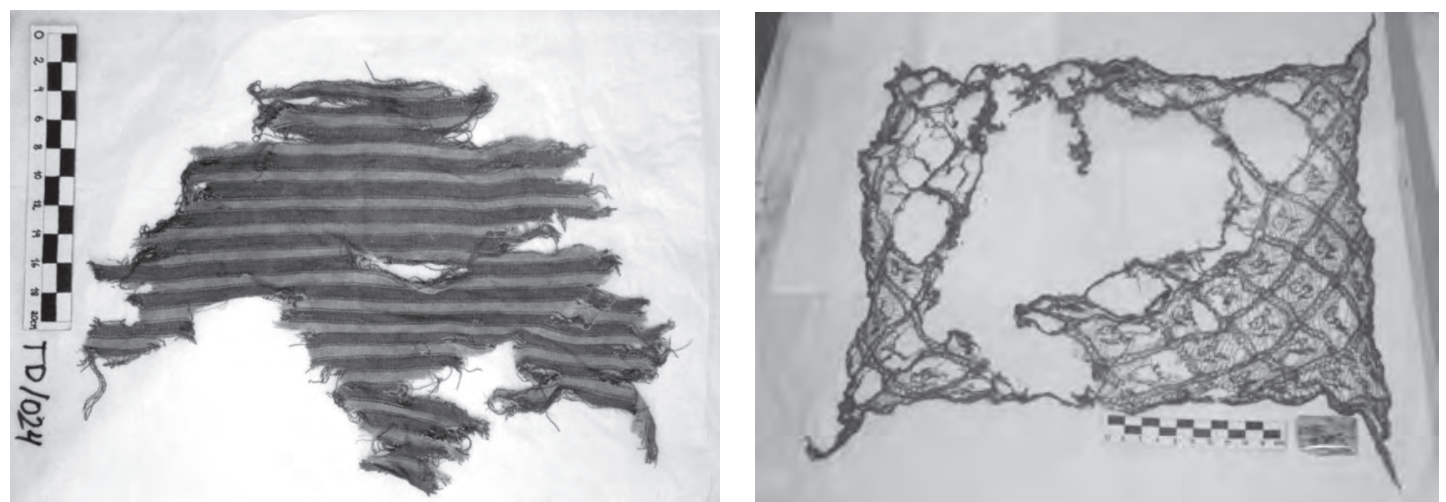

Figura 41 (Izquierda): Tejido Chancay listado. 7. Figura 42 (derecha): Gasa Chancay con decoración de rombos diagonales, en cuyo interior hay aves y olas marinas.
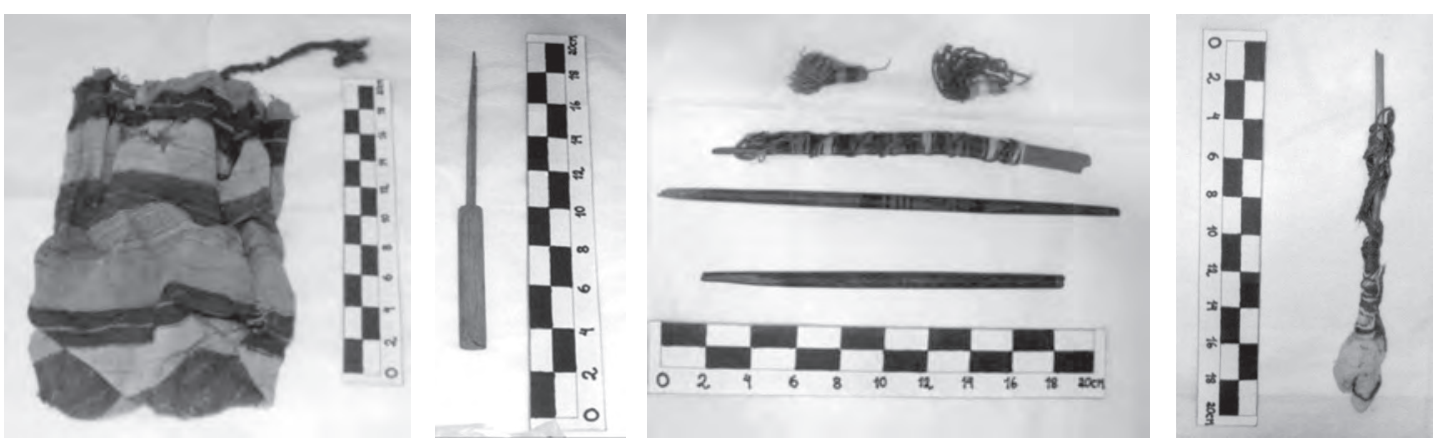

Figura 43 (Izquierda): Bolsa (chuspa) Chancay con bandas horizontales en crema, beige y marrón. Figura 44 (centro izquierda): Huso metido en una caña. Figura 45 (centro derecha): Husos Chancay, caña con hilos enrollados y flecos de color amarillo y rojo. Figura 46 (derecha): Pincel.

\section{A. Botellas}

Tipo 1: Botella sin asas, de $26 \mathrm{~cm}$ de alto, boca de $6 \mathrm{~cm}$ de diámetro, cuello tubular convergente de $8 \mathrm{~cm}$ de alto, con la representación de un ser antropomorfo en alto relieve en la parte anterior inferior del cuello, así como incisiones en la parte posterior que definen el cabello. El cuerpo es globular achatado en la parte posterior y anterior. Todo el cuerpo presenta volutas en alto relieve, representando una chirimoya. La vasija es de pasta naranja. Presenta problemas de salinidad, lo que define su mal estado de conservación. 

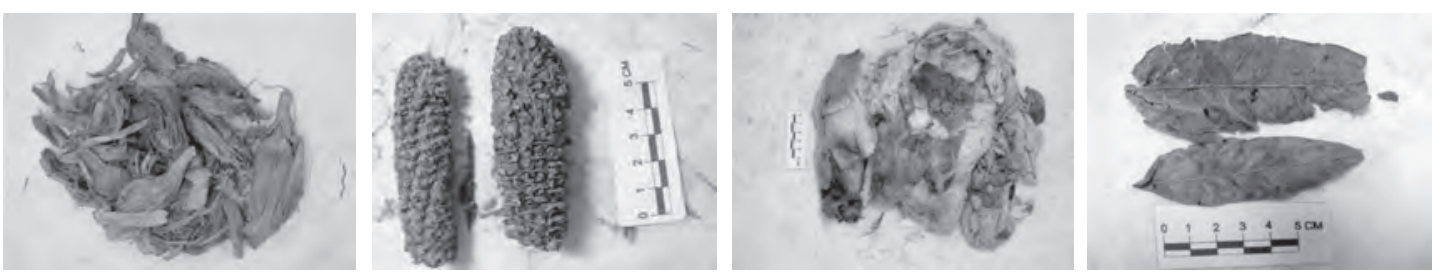

Figura 47 (Izquierda): panca de maíz. Figura 48 (centro izquierda): corontas de maíz. Figura 49 (centro derecha): algodón con semillas. Figura 50 (derecha): Hojas de pacae.

\section{TEXTILES}

Se han encontrado numerosos textiles que cubrían a los individuos, textiles personales, así como otros textiles que acompañaban al individuo. Los textiles de la Cultura Chancay, en base a la materia prima, se pueden clasificar en cuatro grandes y comunes grupos: 1. Los textiles elaborados con fibras de algodón, los más comunes y diversos, por ser el algodón, un producto intensamente sembrado en el valle; 2. Los textiles elaborados de fibras de camélidos, también presentes en mediana proporción; 3. Los textiles elaborados con cabellos humanos, los cuales eran trenzados e hilados, conformando incluso finos hilos; y 4. Los textiles elaborados en fibras vegetales, como junco, totora, tallos de maíz, entre otras especies gramíneas.

Entre los textiles más comunes encontrados resaltan aquellos de algodón, de color crema o beige, de 1x1, de decoración listada, mediante bandas verticales medianas alternadas en colores marrón, griss y beige (de fondo). Entre las bandas figuran líneas de color negro y marrón. La gran densidad de este tipo de textil, observados no solo en los fardos o entremezclada con las capas; sino en otras áreas funerarias Chancay del valle Chancay y del valle de Huaura, hace pensar que se trataría de un traje típico, doméstico y de carácter nacional. Predominan también los textiles tipo gasa, en color blanco, crema, marrón, negro (hecho con cabellos humanos) o incluso en azul; algunos sin decoración interna y otros con bandas de rombos diagonales, que a su vez contienen aves marinas, peces y olas. Hay otros textiles llanos de color crema, de técnica 1x1. Además hay fajas y vinchas hechas mediante tapicería de colores variados, principalmente amarillo, rojo, marrón y crema. Son muy comunes los tejidos con decoración negro sobre crema, pues al igual que en la cerámica, sobre la tela de fondo crema se tejieron los motivos decorativos en color negro, así como hay tejidos listados de fondo crema con bandas verticales en color marrón. Este sería otro tejido tipo nacional Chancay. Hay presencia también de tapices ranurados. Hay un tejido singular, conformado por una chuspa (bolsa) elaborado mediante la técnica de tapiz ranurado, de fondo crema, con decoración de aves alineadas diagonalmente en color marrón. Se halló tejidos anudados o entrelazados tipo redes que servían a modo de mallas que eran colocadas en la cabeza.

\section{RESTOS ÓSEOS}

Con respecto a las características de los restos óseos humanos identificados en los contextos funerarios, tanto enfardelados como simples, estamos preparando un artículo específico sobre los análisis de antropología física que hemos realizado.

\section{OBJETOS DE MADERA}

Como parte de los materiales que acompañaban al individuo del contexto 21 se identificó dos troncos de madera a modo de báculos, hechos en huarango. Además se halló en asociación a los individuos numerosos husos que describimos en el siguiente punto. Se halló un instrumento de madera de chonta, de $19 \mathrm{~cm}$ de largo por $3 \mathrm{~cm}$ de ancho, apuntado en uno de sus extremos y redondeado en el otro, de aparente función textil en el telar. 


\section{INSTRUMENTOS TEXTILES}

Se ha recuperado una considerable cantidad de instrumentos utilizados en actividades textiles, asociados a la mayoría de individuos. Entre los más resaltantes figuran los husos. Son elaborados de troncos y tallos de madera de huarango, finamente tallados, con extremos apuntados, y con decoración pictórica en la parte media del cuerpo, formado por bandas, espirales o líneas de color negro, en algunos casos alternados con el fondo natural. La medida promedio de estos instrumentos es de $19 \mathrm{~cm}$ de largo por $1 \mathrm{~cm}$ de ancho. Fung (Fung 1960: 109) reportó el hallazgo en Macatón, de husos de características similares a los que nosotros hemos hallado, con decoración de círculos medianos y pequeños, con líneas pintadas en negro. Doce de los husos que halló Fung estaban envueltos por hilos de color blanco. En nuestra investigación se recuperó un total de 8 husos de tamaños y características similares. Se pudo recuperar además, espinas de cactus y tallos trabajados apuntados, los que fueron utilizados como agujas. Se halló además, ovillos de hilos de colores marrón, blanco, amarillo, rojo y beige, algunos envueltos en sí mismo y otros alrededor de cañas. Se han encontrado también cabellos humanos hilados y trenzados alrededor de una caña.

\section{MATERIAL BOTÁNICO}

Entre los materiales arqueológicos recuperados se encontró gran cantidad de restos botánicos. Estos se encontraban entremezclados con la tierra del relleno de las estructuras, conformando gruesas capas de relleno, en el interior de los fardos, o como parte de las ofrendas, en el interior de vasijas o individuales. Con respecto a las partes de las especies identificadas, figuran: raíces, semillas, tallos, hojas y frutos. La especie que en mayor proporción se ha identificado es el pacae, Inga feullei, especie que era muy diversa en el valle, pues hasta la actualidad es muy común encontrarla en casi todas las chacras del valle. Se ha encontrado gran cantidad de semillas, vainas, así como tallos y hojas como parte del relleno. Otra especie muy recurrente es el maíz, se ha encontrado corontas de diversos tamaños, las más grandes de $18 \mathrm{~cm}$ de largo, así como granos, tallos y pancas.

Entre las especies identificadas, en orden de proporción tenemos:
1. Inga feullei - pacae
9. Scirpus americanus -junco
2. Zea mayz - maíz
10. Prosopis limensis - algarrobo
3. Aiphanes horrida - chonta
11. Shinus molle - molle
4. Gossypium barbachense - Algodón
12. Litoxirum coca-coca
5. Pouteria lúcuma - lúcuma
13. Gynerium sagitatum - caña brava
6. Arachis hipogaea-maní
14. Cesalpinia tara - tara
7. Lagenaria siceparia - mate
8. Tipha domingensis - totora

\section{MATERIAL LÍTICO}

No se han encontrado artefactos líticos, salvo un pequeño percutor con alto grado de desgaste procedente de la unidad 1.

\section{RESTOS FAUNÍSTICOS}

Se ha encontrado en asociación a los contextos funerarios, regular cantidad de restos óseos de animales que han sido sacrificados para cumplir la función de acompañamiento del individuo a modo de ofrenda. El más común es el camélido, principalmente huesos largos de extremidades, vértebras y cráneos de Llama (Lama glama glama). Así mismo se ha identificados restos óseos de canes (Canis lupus familiaris) y cuyes (Cavia sp.). Durante la cultura Chancay era muy común el sacrificio de canes a modo de ofrendas como acompañamiento de los individuos en la estructura funeraria, o como ofren- 
da de cualquier ceremonia religiosa. Se ha identificado también restos óseos de aves de litoral, muy diversas en esta zona del valle Chancay, que en algunos casos vivían en los extensos humedales que existían en el área.

\section{OTROS MATERIALES}

Se ha recuperado una gran cantidad de soguillas y trenzados hechos de hilos de lana de camélido, de hilos de algodón, de hilos de cabellos humanos y de fibras vegetales. Así mismo se halló redes para pesca, flecos de hilos aflorantes de hasta cuatro colores alternos de color amarillo y rojo que habría servido como adornos de textiles o para colocar en las orejas de los camélidos o personas, y algo que llama la atención son dos pequeñas cañas cruzadas y envueltas por bandas de hilos de hasta tres colores, preferentemente en amarillo, blanco, marrón y rojo, algunas definiendo en el centro una figura romboidal o cuadrangular. En la unidad 4 se halló un alisador de cerámica de pasta color rojo, acabado alisado, de forma circular, fragmentado, de $6 \mathrm{~cm}$ de largo por $4,5 \mathrm{~cm}$ de ancho. Se recuperó además, un pedazo de caña delgada envuelto con hilos rojos y marrón conteniendo en su extremo un pedazo grande de algodón que envuelve la punta, atado en su alrededor con hilos para fijación, lo que correspondería a un pincel para pintar (Art 31-A). Se halló también una caña pequeña de $12 \mathrm{~cm}$ de largo, alrededor del cual se ha enrollado hilos en tres colores, en los extremos de color rojo y en el centro blanco (Art 24-A).

Se halló un collar de $42 \mathrm{~cm}$ de largo en todo su contorno, hecho mediante tranzado de algodón con flecos aflorantes de color crema y marrón. Presenta un hilo en el trenzado de color rojo (Art 26). Hay otro elemento como collarín de dos cuerpos, con flecos aflorantes, al parecer un elemento interior de la vestimenta (Art 28-B).

\section{INTERPRETACIONES Y CONCLUSIONES}

Los datos que hemos presentado, en especial la descripción de las características de los contextos funerarios recuperados en el sitio de Macatón, son de gran importancia, puesto que son una de las pocas referencias sobre los contextos funerarios Chancay. Pues, salvo el artículo de Rosa Fung (Fung 1960) sobre la tumba de Macatón, la obra de Hilda Vidal (Vidal 1969) donde describe los contextos funerarios Chancay recuperados en Pasamayo, los artículos de Miguel Cornejo Guerrero (Cornejo 1985, 1991, 1992, 1999) en la cual reconstruye documentalmente los contextos funerarios excavados por Hans Horkheimer en Lauri, y los artículos en que Arturo Ruiz Estrada (Ruiz 1981, 1991, 1998, 2007) detalla el hallazgo de contextos funerarios Chancay en el valle de Huaura, no existen mayores datos, sobre las características y la importancia de las prácticas mortuorias para la sociedad Chancay.

Miguel Cornejo Guerrero (Cornejo 1991: 84) realizó una tipología morfológica de los contextos funerarios Chancay, basándose en una muestra de 18 contextos funerarios del sitio arqueológico de Lauri, excavados por Hans Horkheimer en 1963. Cornejo realiza una tipología de las estructuras funerarias en base a su morfología, señalando que: «Las tumbas estudiadas presentan algunas características comunes; en primer lugar no presentan arquitectura, están hechas básicamente modelando y compactando el terreno (excepto La-1, La-9, y La-10). En segundo lugar, las dimensiones nunca guardan un patrón regular, las relaciones entre largo, ancho y altura son variables y no se ajustan a ninguna referencia registrada aún». En base a la morfología, Cornejo plantea seis tipos de estructuras funerarias, el tipo «A» de planta rectangular o cuadrangular y dimensiones variables, de paredes rectas y pisos planos; el tipo «B» de planta rectangular o cuadrangular y dimensiones variables, con un descanso por encima del nivel del suelo orientado al Oeste; el tipo «C» de planta rectangular o cuadrangular y dimensiones variables, con un descanso por encima del nivel del suelo orientado al Oeste y dos estribos, orientados al Norte y Sur cada uno; el tipo «D» de planta rectangular, con dos plataformas 
de adobes a modo de camas donde se coloca el fardo; el tipo «E» de planta circular, de mayor altura que el diámetro de la base y la boca, sin elementos; y el tipo «F» de planta circular con una cámara adyacente al tubo que le sirve de antecámara. Los cuatro primeros tipos: A, B, C y D corresponden a la segunda mitad del Intermedio Tardío, siendo sin embargo, la fase D más antigua que las otras. Por su parte el tipo E corresponde a inicios del Intermedio Tardío, mientras que el tipo F corresponde al Horizonte Medio 3 y 4 (Ibid: 84-88).

Los contextos funerarios hallados en las excavaciones en Macatón se caracterizan por no presentar una estructura funeraria bien elaborada, no presentan arquitectura, se trata solo de matrices de forma ovalada en cuyo interior han sido colocados los individuos en fardos, notándose muchas superposiciones de estructuras, debido al enterramiento de una alta densidad de contextos en un espacio reducido. Las características de las estructuras funerarias de Macatón estarían en mayor relación con el tipo «E» planteado por Cornejo, lo que no significa que sean del mismo tipo, pues los de Macatón son de menor profundidad. Es importante señalar en base al análisis de los materiales hallados disturbados en las capas, se ha podido definir que algunas estructuras habrían estado compuestas por varios niveles de tierra, interrumpidos por techos hechos a base de cañas o juncos dispuestos horizontalmente. Además la presencia en la unidad 5 de una huanca dispuesta en posición vertical sobre los contextos funerarios identificados, evidencia la doble función que esta cumplió, tanto como marca del contexto, y como elemento ceremonial.

Tabla 2: Características de los contextos funerarios recuperados en Macatón (Temporada 2009):

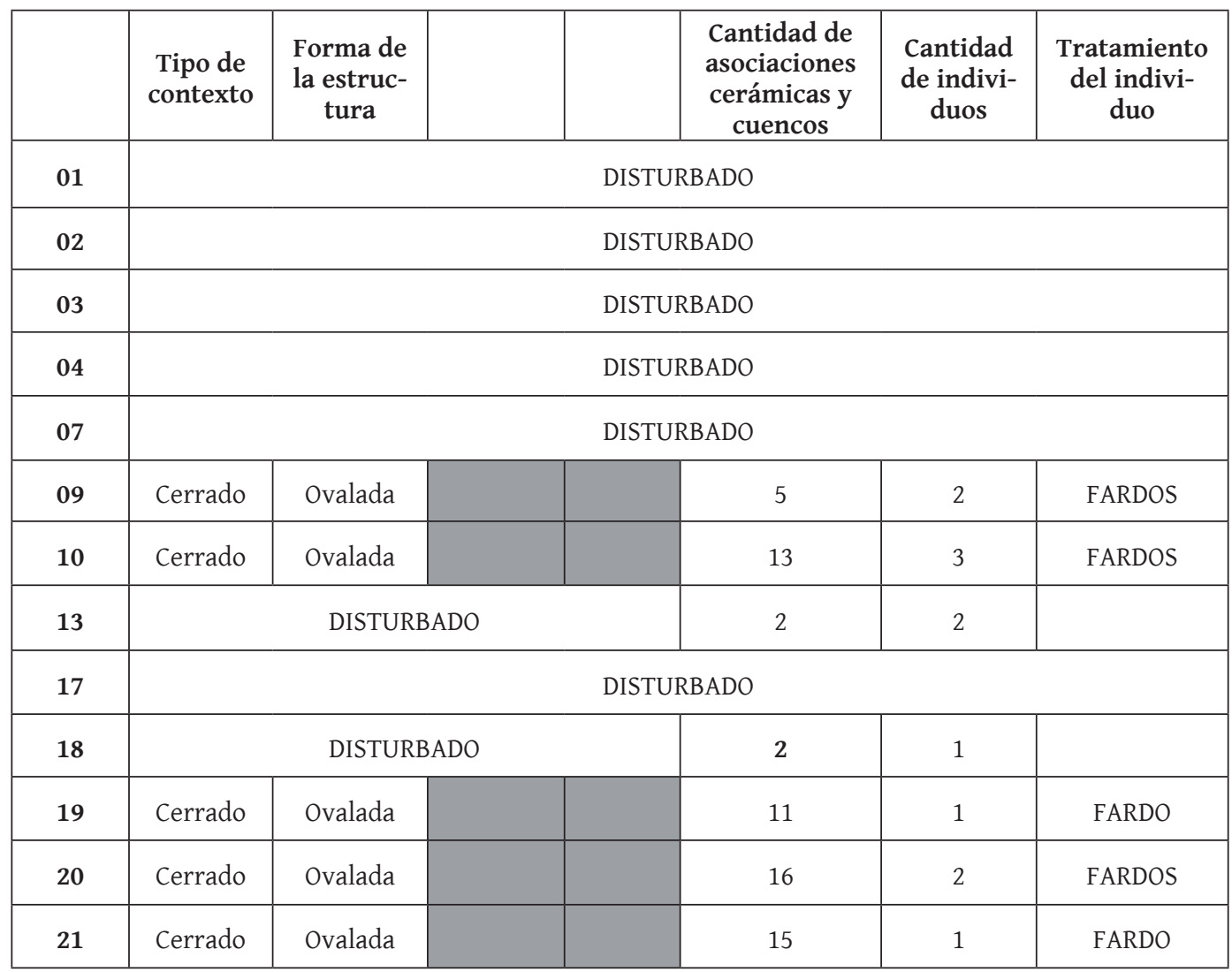


Otra característica importante de resaltar es con respecto al tratamiento del individuo, la mayoría de los individuos enfardelados son de sexo masculino, y se encuentran en algunos casos acompañados de neonatos colocados también al interior de fardos y dispuestos en posición extendida. Como señalamos, líneas arriba nos encontramos preparando un artículo específico sobre los análisis de antropología física de los individuos. Sin embargo, debemos precisar que todos se encontraban en el interior de fardos, y tres de ellos con falsa cabeza. La orientación de los individuos es preferentemente hacia el Este y Norte.

Con respecto a los materiales asociados, la presencia de vasijas es una constante en los contextos investigados, y se conoce que era una práctica muy común del ritual funerario. La mayoría de ejemplares pertenecen al estilo Chancay, principalmente en sus tipos negro sobre blanco y base crema. Hay un ejemplar de estilo Lauri Impreso, uno de Teatino, y uno de estilo Pativilca-Supe.

La poca inversión de fuerza laboral para la elaboración de las estructuras funerarias, así como la relativa cantidad de materiales asociados, nos hace referencia a que se trata de individuos de status medio en la sociedad. Pues, de tratarse de personajes de status superior, familiares de algún curaca, o él mismo, tendrían una estructura de mayor profundidad, posiblemente con arquitectura funeraria, y con una variedad de materiales asociados hasta en diferentes niveles verticales, como se ha hallado en otros sitios, evidenciando un bien elaborado ritual funerario de larga duración.

Con respecto a la asociación cronológica la mayoría de contextos funerarios hallados corresponden al Intermedio Tardío. Hay sin embargo, dos contextos que serían más antiguos. En el contexto 9, en la unidad 2, se halló en asociación a los individuos, seis conjuntos de asociaciones, entre ellas un cántaro de estilo Pativilca con decoración cara gollete en alto relieve y botones en el cuerpo. En asociación a este se halló vasijas de estilo Chancay. La contextualización de vasijas de estilo Chancay con vasijas Pativilca de las fases finales del Horizonte Medio, evidencia que en algún momento estos estilos coexistieron en el tiempo, además de evidenciar que este contexto corresponde o bien a inicios del Intermedio Tardío, lo que señalaría que el estilo Pativilca se extiende temporalmente hasta el 1100 d.C.; o lo más probable, que el estilo Chancay comience su desarrollo en las etapas finales del Horizonte Medio (Horizonte Medio 4). Esto será definido en futuras investigaciones. Esto sería corroborado por el contexto 10 de la misma unidad, donde se halló entre las 13 vasijas asociadas a los tres fardos, una vasija de estilo Teatino (también del Horizonte Medio) en asociación a vasijas de estilo Chancay principalmente del tipo negro sobre blanco. Tentativamente proponemos que estos dos contextos funerarios corresponden al Horizonte Medio 4.

Por su parte, pensamos que el contexto 19 de la capa D en la unidad 5, corresponde al entierro de un infante Chancay del Horizonte Tardío, pues el hecho de estar asociado directamente a la huanca y estar sellado por dos pisos continuos asociados directamente a los muros de tapiales del recinto donde se emplazó la unidad, nos da esta inferencia. Las vasijas asociadas al individuo son todas Chancay, de engobe crema y domésticas sin decoración, con leve influencia Tawantinsuyu, de borde ligeramente evertido.

Casi todos los individuos presentaban en los fardos un textil llano de 1x1, de algodón de fondo crema, con bandas verticales en colores marrón, azul y crema en diferentes tonalidades, lo que hace pensar que este sería una especie de prenda doméstica nacional identificatoria. Pues es muy común encontrar este tipo de textil en grandes cantidades en los cementerios Chancay. Se ha encontrado además otros tipos de textiles, entre los que destacan las gasas y tapices, así como redes y soguillas hechas de cabellos humanos. La mayoría de individuos tenían asociados instrumentos textiles, como los husos, pensamos que esta habría sido una práctica doméstica cotidiana, alternada con las labores en el campo, aunque no se han hallado instrumentos agrícolas. 


\section{Agradecimientos}

Un especial reconocimiento a la empresa Famesa explosivos, entidad que auspició el desarrollo de los trabajos de excavación, apoyándonos con los materiales de embalaje y campo. La oficina Zonal de Huacho de Construyendo Perú, dirigido por el Lic. Aldo Hermenegildo, financió el pago del personal. Un reconocimiento al equipo de arqueólogos que participaron en las excavaciones y gabinete: al Bach. Anibal Apaico Flores (UNSCH), Lic. Rafael Mallco Huarcaya (UNSLG), Bach. Jorge Alejandro Rosas Fernández (UNSCH), Bach. Cirilo Cornejo Condeña (UNSLG), Bach. Rubén Cisneros Cárdenas (UNSCH), Bach. Nancy Santander Málaga (UNMSM), Lic. Luis Ricardo Angulo Paredes (UNSLG), Bach. Leandro Maykol Tinoco Rivas (UNSCH), Bach. Luciano Máximo Cuva Samaniego (UNSLG), Bach. Robert Henry Vilcatoma Navarro (UNSCH), Lic. Martha Vásquez Gutiérrez (UNMSM) y el estudiante Rony Alex Huamaní Luján (UNSLG). A la colega y amiga Lic. Milena Ramírez Martínez por todo el apoyo brindado; así como a los amigos y vecinos del Centro Poblado El Ángel, en especial al Señor Jara, gran dirigente, y su familia.

\section{BibliografíA}

AGURTO CALVO, Santiago y Alfredo SANDOVAL

1974 Inventario, catastro y delimitación del patrimonio arqueológico del valle del río Chancay. Lima: INC. Ms.

BONAVÍA, Duccio

1967 «La Misión Arqueológica Chancay». Revista del Museo Nacional. 33: 402-403. Lima.

BUITRÓN CAÑAMERO viuda de CAFITI

2007 «Estudios arqueológicos in situ del Dr. Andrés Marmol Castellanos». KULLPI. Investigaciones culturales en la provincia de Huaral y el Norte chico. 3(3): 351-353. Mayo, Huaral.

CASTAÑEDA PARDO, Pedro

2005 Conociendo la provincia de Huaral. Lima: W. B. Impresores, editores. 322 p.

COLÁN, Hermógenes; Domingo DíAZ y Jorge MONTALVO

1936 «Estudios arqueológicos en el valle de Chancay». En: J. Montalbo (ed.) Álbum de Oro Huaralino. T.II, pp. 136-142. Lima: Ed. Mora.

CORNEJO GUERRERO, Miguel

1985 Análisis del material cerámico excavado por Hans Horkheimer en 1961, Lauri, valle de Chancay. Memoria para optar al grado de Bachiller (Tesis). PUCP, Facultad de Letras y Ciencias Humanas. Lima.

1991 «Patrones Funerarios y discusión cronológica en Lauri, valle de Chancay». Estudios sobre la cultura Chancay, Perú: 83-113. Cracovia, Polonia.

1992 «Cronología y costumbres sepulcrales en Lauri, valle de Chancay». Estudios de Arqueología Peruana, D. Bonavía (ed.), Lima: Fomciencias.

1999 «La sociedad Prehispánica Chancay a través de la muerte». Boletín de Lima. 21(118): 27-44. Lima: Ed. Los Pinos. Republicado en: SEQUILAO. Revista de Historia, Arte y Sociedad. VIII(13): 31-50 (2001). Lima.

DILLEHAY, Tom

1974 Competition and cooperation in a prehispanic multietnic system in the central Andes.Tesis doctoral, University of Texas-Austin.

DUVIOLS, Pierre

1986 Cultura andina y represión. Procesos y visitas de idolatrías y hechicerías en Cajatambo, Siglo XVII. Cusco: Centro de Estudios Rurales Andinos Bartolomé de Las Casas. 568 p.

ELIAS IPINZE, Jesús

2005 La antigua provincia de Chancay, siglos XVI-XVIII. Selección y prólogo de Filomeno Zubieta Núñez. Huacho, 207 p.

ENGEL, Fréderic

1970 Las lomas de Iguañil y el complejo las Haldas. Lima: Universidad Nacional Agraria La Molina. 58 p. 
1987 De las begonias al maíz: vida y producción en el antiguo Perú. Lima: Universidad Nacional Agraria, Centro de Investigaciones de Zonas Áridas.

FLORES BLANCO, Luis Angel

2009 «Prácticas mortuorias Chancay en el sector «X» de Caral, valle de Supe». KULLPI. Investigaciones culturales en la provincia de Huaral y el Norte chico. 4(4): 15-34. Octubre, Huaral.

FUNG PINEDA, Rosa

1960 «Huaral: Inventario de una tumba saqueada». Etnología y arqueología, 1(1): 74-129. Lima.

GALLARDAY BOCANEGRA, Tomás

1982 Arcillas de la costa central peruana: cuenca del río Chancay. Lima: UNMSM, Seminario de Historia Rural Andino. $66 \mathrm{p}$.

HORKHEIMER, Hans

1962 «Arqueología del valle Chancay». Exposición en el Museo de Arte. Lima.

1965 «Identificación y bibliografía de importantes sitios prehispánicos del Perú». En: Arqueológicas 8. Lima: MNAAHP.

1970 «Chancay prehispánico: Diversidad y belleza». En: R. Ravines (comp.) 100 años de arqueología en el Perú, Lima: Petroperú.

JIMÉNEZ BORJA, Arturo

1981 «Introducción a la cultura Chancay». En: Lavalle y Lang (eds.) Culturas precolombinas: Chancay. Colección de arte y tesoros del Perú, pp. 9-48. Lima: BCP.

KAULICKE, Peter

1997a Patrones funerarios en Ancón. Lima: PUCP.

1997b La muerte en el antiguo Perú. Lima: PUCP.

2000 Memoria y muerte en el antiguo Perú. Lima: PUCP.

KRZANOWSKI, Andrzej

1986 Cayash prehispánico. Cracovia: Polska Academia Nauk.

1991 «Chancay: una cultura desconocida.» En: Estudios sobre la cultura Chancay, Perú: 19-36. Cracovia.

1991 «Observaciones sobre la arquitectura y patrón de asentamiento de la cultura Chancay». En: Estudios sobre la cultura Chancay, Perú: 37-56. Cracovia.

1991 «Influencia inca en los valles de Huaura y Chancay». En: Estudios sobre la cultura Chancay, Perú: 189214. Cracovia.

2008 Kultura Chancay. Środkowe wybrzeże Perú u schyłku epoki prekolumbijskiej (X-XVI w). Polonia: Instytut Amerykanistyki I Studiow Latynoamerykanistyc znych. Uniwersytetu Jagiellonskiego. 225 p.

LAVALLE, José Antonio de y Werner LANG

1981 Culturas precolombinas: Chancay. Colección: Arte y Tesoros del Perú, Lima.

MARMOL CASTELLANOS, Andrés

2007a «Museo de sitio de Huaral». KULLPI. Investigaciones culturales en la provincia de Huaral y el Norte chico. 3(3): 354-363. Mayo, Huaral.

$2007 b$ «Nuestro patrimonio arqueológico está en peligro de desaparecer». KULLPI. Investigaciones culturales en la provincia de Huaral y el Norte chico. 3(3): 364-367. Mayo, Huaral.

NEGRO, Sandra

1991 «Arquitectura y sistemas constructivos en los asentamientos de la cultura Chancay». Estudios sobre la cultura Chancay, Perú: 57-82. Cracovia.

ONERN

1969 Inventario, evaluación y uso racional de los recursos naturales de la costa: valle Chancay-Huaral. 2 tomos. Lima: Oficina Nacional de Evaluación de Recursos Naturales (ONERN).

ROSTOROWSKI DE DIEZ CANSECO, María

1978 Señoríos indígenas de Lima y Canta. Lima: IEP. 280 p.

ROSAS CUADROS, Emilio

1976 La provincia de Huaura en la Colonia y la Emancipación. Lima. 375 p. 
1992 Historia de la provincia de Huaral. Lima.

RUIZ ESTRADA, Arturo

1981 Investigaciones arqueológicas en Cerro Colorado. Informe, Huacho, 14 p.

1991 «El entierro de un músico prehispánico en Huacho, valle de Huaura». Estudios sobre la cultura Chancay, Perú: 133-153. Cracovia.

1998 «Sobre el hallazgo de momias tatuadas en Huacho». Revista INSULA 4: 6-7. Febrero.

2007 «Notas sobre el entierro de un niño de la cultura Chancay de Huacho». Investigaciones Sociales, 18: 151-177. Lima: UNMSM, Revista del Instituto de Investigaciones Histórico Sociales. Facultad de Ciencias Sociales.

SHADY SOLÍS, Ruth y Arturo RUIZ ESTRADA

1979 «Huaura-Costa Central. Interacción regional en el periodo Intermedio Temprano». Arqueológicas. № 18. Lima: MNAAHP.

SILVA ESQUÉN, Miguel

2009 «Análisis de Figurinas del valle de Huaura». KULLPI. Investigaciones culturales en la provincia de Huaral y el Norte chico. 4(4): 77-94. Octubre, Huaral.

SILVA, Jorge y Joyce MARCUS

1988 «Los cocales del valle Chillón. Evidencia arqueológica y contexto ecológico». En: M. Rowstorowski (comp.) Conflicts Over Coca Fields in XVIth-Century Perú. Lima: IEP.

TARAZONA GAMARRA, Javier

1997 «Macatón: Un viejo pueblo en el valle de Chancay». Los Especiales de Huacho. 9: 6-10. Huacho.

VALLEJO BERRIO, Francisco

2010 «Evidencias arqueológicas de un nuevo estilo cerámico en el valle de Huaura para el periodo Intermedio tardío: El paso del Horizonte Medio al Intermedio tardío». En: R. Romero y T. Pavel (eds.) Arqueología en el Perú. Nuevos aportes para el estudio de las sociedades andinas prehispánicas: 299248. Lima.

VAN DALEN LUNA, Pieter

2002a Estudios de la arquitectura en el sitio arqueológico de Cuyo, valle medio del río Chancay. Informe final presentado al Instituto Nacional de Cultura, $167 \mathrm{p}$.

2002b Arqueología y etnohistoria de los periodos tardíos en la provincia de Huaral. Municipalidad Distrital de Chancay. 20 p. Republicado Revista CEAR, UNMSM, 2004.

2004a «Los valles de Huaura y Chancay dentro del imperio del Tahuantinsuyo» En: Boletín del patronato de defensa del patrimonio cultural del valle de Huaura y Ambar. III(16): 3-8. Junio.

2005 «Proceso cultural Prehispánico en Chancayllo, valle de Chancay.» KULLPI. Investigaciones culturales en la provincia de Huaral y el Norte chico. 2(2): 55-75. Mayo, Huaral.

2006 Informe final del proyecto de investigación arqueológica y revalorización cultural en el sitio de Pampa de Animas, Valle de Huaura. Informe final presentado al INC. Marzo. 240 p.

2007a «Reconocimiento arqueológico en la cuenca alta del río Chancay-Huaral (distritos de Atavillos Alto, Santa Cruz de Andamarca y Pacaraos). Nuevos datos para comprender los procesos socioculturales Atavillos». KULLPI. Investigaciones culturales en la provincia de Huaral y el Norte chico. (3)3: 57-148. Mayo, Huaral.

2007 "Análisis de un quipu Tahuantinsuyo procedente de Lauri, valle de Chancay». KULLPI. Investigaciones culturales en la provincia de Huaral y el Norte chico. 3(3): 191-215. Mayo, Huaral.

2007c «Resultados de las investigaciones arqueológicas en Pampa de Animas, valle de Huaura». En: Guara. № 3: 16-24. Huacho: Museo Arqueológico de la UNJFSC. Noviembre.

2008 Los ecosistemas arqueológicos en la cuenca baja del río Chancay - Huaral. Su importancia para el desarrollo de las formaciones sociales prehispánicas. Lima: Ed. Gutemberg. 185 p.

2009 «Sistemas de asentamiento en el valle medio del río Chancay». KULLPI. Investigaciones culturales en la provincia de Huaral y el Norte Chico. 4(4): 240-315. Setiembre, Huaral.

2010a «Análisis de un documento de extirpación de idolatrías procedente del complejo arqueológico Lumbra, valle medio del río Chancay-Huaral». Investigaciones Sociales, № 24. Instituto de Investigaciones Histórico Sociales. Facultad de Ciencias Sociales. Universidad Nacional Mayor de San Marcos. Junio. 
2010b Introducción al estudio arqueológico de Hualmay, valle de Huaura. Lima: Ed. Gutemberg. 84 p.

VAN DALEN LUNA, Pieter y Miguel CASTILLO RODRÍGUEZ

2004 «Arqueología de la región de Quilca: zona de interacción prehispánica entre los valles de Chillón y Chancay». KULLPI. Investigaciones culturales en la Provincia de Huaral y el Norte Chico. 1: 3-21. Diciembre, Pieter van Dalen Luna, editor. Huaral.

VIDAL VIDAL, Hilda

1969 Excavaciones arqueológicas en Pasamayo. Lima: Patronato y Museo de sitio de Ancón.

VILLAR CORDOVA, Pedro

1982 [1935] Arqueología del departamento de Lima. 2e edición. Lima: Ed. Atusparia.

WATANABE DE AMANO, Rosa

1996 «La trascendencia de los sitios arqueológicos» En: Boletín de Actividades Fundación Museo Amano. Año 6, № 8, Lima. 